\title{
Spatiotemporal variability of snow depth across the Eurasian continent from 1966 to 2012
}

\author{
Xinyue Zhong ${ }^{1,3}$, Tingjun Zhang ${ }^{2}$, Shichang Kang ${ }^{3,4}$, Kang Wang ${ }^{5}$, Lei Zheng ${ }^{6}$, Yuantao Hu ${ }^{2}$, and Huijuan Wang ${ }^{2}$ \\ ${ }^{1}$ Key Laboratory of Remote Sensing of Gansu Province, Cold and Arid Regions Environmental and Engineering Research \\ Institute, Chinese Academy of Sciences (CAS), Lanzhou 730000, China \\ ${ }^{2}$ Key Laboratory of Western China's Environmental Systems (Ministry of Education), College of Earth and Environmental \\ Sciences, Lanzhou University, Lanzhou 730000, China \\ ${ }^{3}$ State Key Laboratory of Cryospheric Science, Cold and Arid Regions Environmental and Engineering Research Institute, \\ CAS, Lanzhou 730000, China \\ ${ }^{4}$ CAS Center for Excellence in Tibetan Plateau Earth Sciences, Beijing 100101, China \\ ${ }^{5}$ Institute of Arctic and Alpine Research, University of Colorado Boulder, Boulder, Colorado, 80309, USA \\ ${ }^{6}$ Chinese Antarctic Center of Surveying and Mapping, Wuhan University, Wuhan 430079, China
}

Correspondence: Xinyue Zhong (xyzhong@1zb.ac.cn) and Tingjun Zhang (tjzhang@1zu.edu.cn)

Received: 18 July 2016 - Discussion started: 12 September 2016

Revised: 24 November 2017 - Accepted: 6 December 2017 - Published: 22 January 2018

\begin{abstract}
Snow depth is one of the key physical parameters for understanding land surface energy balance, soil thermal regime, water cycle, and assessing water resources from local community to regional industrial water supply. Previous studies by using in situ data are mostly site specific; data from satellite remote sensing may cover a large area or global scale, but uncertainties remain large. The primary objective of this study is to investigate spatial variability and temporal change in snow depth across the Eurasian continent. Data used include long-term (1966-2012) ground-based measurements from 1814 stations. Spatially, long-term (1971-2000) mean annual snow depths of $>20 \mathrm{~cm}$ were recorded in northeastern European Russia, the Yenisei River basin, Kamchatka Peninsula, and Sakhalin. Annual mean and maximum snow depth increased by 0.2 and $0.6 \mathrm{~cm} \mathrm{decade}^{-1}$ from 1966 through 2012. Seasonally, monthly mean snow depth decreased in autumn and increased in winter and spring over the study period. Regionally, snow depth significantly increased in areas north of $50^{\circ} \mathrm{N}$. Compared with air temperature, snowfall had greater influence on snow depth during November through March across the former Soviet Union. This study provides a baseline for snow depth climatology and changes across the Eurasian continent, which would significantly help to better understanding climate system and
\end{abstract}

climate changes on regional, hemispheric, or even global scales.

\section{Introduction}

Snow depth, snow water equivalent (SWE), and snow density are all important parameters for water resource assessment, hydrological, and climate model inputs and validation (Dressler et al., 2006; Lazar and Williams, 2008; Nayak et al., 2010). Changes in snow cover, including snow depth and snow area extent, serve as an indicator of climate change because of their interactions and feedbacks with surface energy and moisture fluxes, hydrological processes, and atmospheric and oceanic circulations (Brown and Goodison, 1996; Armstrong and Brown, 2008; King et al., 2008). Changes in snow depth can have dramatic impacts on weather and climate through the surface energy balance (Sturm et al., 2001), soil temperature and frozen ground (Zhang, 2005), spring runoff, water supply, and human activity (AMAP, 2011).

During winter, the average maximum terrestrial snow cover is approximately $47 \times 10^{6} \mathrm{~km}^{2}$ over northern hemispheric land surfaces (Robinson et al., 1993; IGOS, 2007). A large fraction of the Eurasian continent is covered by snow during the winter season, and some areas are covered by 
snow for more than half a year. There are long-term snow measurements and observations across the Eurasian continent with the first snow depth record dating back to 1881 in Latvia (Armstrong, 2001). These measurements provide valuable data and information for snow cover phenology and snow cover change detection. Many studies on snow depth have focused on local and regional scales over Russia (Ye et al., 1998; Kitaev et al., 2005; Bulygina et al., 2009, 2011; Brasnett, 1999) and the Tibetan Plateau (TP) (Li and Mi, 1983; Ma and Qin, 2012) and have revealed significant regional changes. It has been reported that annual mean snow depth has increased in northern Eurasia and the Arctic during the last 70 years (Ye et al., 1998; Kitaev et al., 2005; Callaghan et al., 2011; Liston and Hiemstra, 2011) with large regional differences (Bulygina et al., 2009, 2011; Ma and Qin, 2012; Stuefer et al., 2013; Terzago et al., 2014). Changes in snow depth are primarily affected by air temperature and precipitation. Ye et al. (1998) and Kitaev et al. (2005) showed that higher air temperatures caused an increase in snowfall in winter from 1936 through 1995, and thus greater snow depth was observed in northern Eurasia. Snow depth distribution and variation are controlled by terrain (i.e., elevation, slope, aspect, and roughness) and vegetation (Lehning et al., 2011; Grünewald et al., 2014; Revuelto et al., 2014; Rees et al., 2014; Dickerson-Lange et al., 2015). Snow depth is closely related to synoptic-scale atmospheric circulation indices such as the North Atlantic OscillationArctic Oscillation (NAO/AO). Kitaev et al. (2002) reported that the NAO index was positively related to snow depth in the northern part of East European Plain of Russia and over western Siberia from 1966 to 1990 but negatively correlated with snow depth in most southern regions of northern Eurasia. You et al. (2011) demonstrated that there was a positive relationship between snow depth and the winter NAO/AO index and between snow depth and Niño 3 region sea surface temperature on the eastern and central TP from 1961 through 2005.

To increase the spatial coverage of snow depth, researchers have used different instruments (e.g., lidar, airborne laser scanning, and unmanned aerial systems) (Hopkinson et al., 2004; Grünewald and Lehning, 2013; Bühler et al., 2016) or developed and/or improved passive microwave snow algorithms (Foster et al., 1997; Derksen et al., 2003; Grippaa et al., 2004; Che et al., 2016). Although snow depth and SWE obtained from passive microwave satellite remote sensing could mitigate regional deficiency of in situ snow depth measurements, they have low spatial resolution $(25 \mathrm{~km} \times 25 \mathrm{~km})$, and the accuracy is always affected by underlying surface conditions and algorithms. Using groundbased snow depth measurements over the Eurasian continent against snow depth obtained from passive microwave satellite remote sensing, Zheng et al. (2015) found that the mean percentage error was greater than $50 \%$ and can be up to $200 \%$. Apart from remote sensing, numerical modeling is often used to obtain spatially complete fields of snow depth and/or SWE (Liston and Hiemstra, 2011; Ji and Kang, 2013; Terzago et al., 2014; Wei and Dong, 2015). However, lowresolution satellite remote sensing data are used as input parameter, which can affect simulation accuracy and do not provide a sufficient time series length. Spatial interpolation is a common method for estimates in areas with sparse data. However, uncertainties and potential biases in spatial interpolation can be introduced due to specific algorithms, especially in complex terrain areas. In addition, data acquisition from large airborne equipment or aerial systems is costly and strict data use limitations apply. Hence, ground-based measurements provide currently available most accurate snow depths over a long time period and a database for verification of remote sensing and model simulations.

The objective of this study is to (i) establish snow depth climatology (1971-2000), (ii) investigate snow depth variability on various scales from 1966 to 2012, and (iii) analyze factors controlling snow depth distribution and changes over Eurasian continent. Snow depth data used in this study are daily or 10-day interval ground-based measurements from 1814 stations. Detailed description of in situ measurements and methodology are described in Sect. 2, with major results, discussions, and conclusions presented in Sects. 3-5, respectively.

\section{Data and methodology}

Snow depth data used in this study include daily measurements from national meteorological stations and 10-day interval measurements from snow course. Measurements of daily snow depth were conducted at 1103 meteorological stations over the Eurasian continent from 1881 to 2013 (Table 1). Snow depth was measured once a day using a graduated stake installed at a fixed point location within the station or by a wooden ruler. Snow depth was measured using the same method across the Eurasian continent, which is also one of the standard elements to be measured on a daily basis (WMO, 1996). Historical snow course data were obtained from the former Union of Soviet Socialist Republics (USSR) from 1966 to 2011. Snow course data include routine snow surveys performed throughout the accumulation season (10day interval) and during snowmelt period (5-day interval) over the former USSR. Snow surveys were conducted over $1-2 \mathrm{~km}$ long transects in both forest and open terrain around each station. Snow depth was measured every $10 \mathrm{~m}$ in the forest and every $20 \mathrm{~m}$ in open terrain. Then final snow depth at each station was determined as the average of all measurements in each snow course survey (Bulygina et al., 2011).

Daily air temperature and precipitation data were obtained from 386 meteorological stations across the former USSR from 1966 to 2010 (Table 1). Snowfall data were derived from daily precipitation and air temperature. Daily precipitation was partitioned into a solid and liquid fraction based 
Table 1. Sources of snow depth data.

\begin{tabular}{llrl}
\hline Dataset & $\begin{array}{l}\text { Spatial } \\
\text { distribution }\end{array}$ & $\begin{array}{r}\text { Number of } \\
\text { stations }\end{array}$ & Source \\
\hline Daily snow depth & $\begin{array}{l}\text { former } \\
\text { USSR }\end{array}$ & 586 & $\begin{array}{l}\text { Russian Research Institute for } \\
\text { Hydrometeorological Information - } \\
\text { World Data Center (RIHMI-WDC); } \\
\text { National Snow and Ice Data Center } \\
\text { (NSIDC), University of Colorado at } \\
\text { Boulder } \\
\text { National Meteorological Information } \\
\text { Center (NMIC) of the China }\end{array}$ \\
& China & 492 & $\begin{array}{l}\text { Meteorological Administration } \\
\text { NSIDC }\end{array}$ \\
& Mongolia & 25 & RIHMI-WDC, NSIDC \\
\hline $\begin{array}{l}\text { Snow depth from } \\
\text { snow courses }\end{array}$ & former & 1044 & \\
\hline $\begin{array}{l}\text { Daily air temperature } \\
\text { and precipitation }\end{array}$ & former & 386 & RIHMI-WDC \\
\hline
\end{tabular}

on daily mean temperature (Brown, 2000). The solid fraction of precipitation, $S_{\text {rat }}$, was estimated by

$$
S_{\text {rat }}=\left\{\begin{array}{ll}
1.0 & \text { for } T_{\text {mean }} \leq-2.0^{\circ} \mathrm{C}, \\
0.0 & \text { for } T_{\text {mean }} \geq 2.0^{\circ} \mathrm{C} \\
1.0-0.25\left(T_{\text {mean }}+2.0\right) & \text { for }-2.0{ }^{\circ} \mathrm{C}<T_{\text {mean }}<+2.0^{\circ} \mathrm{C}
\end{array},\right.
$$

where $T_{\text {mean }}$ is the mean daily air temperature $\left({ }^{\circ} \mathrm{C}\right)$.

Daily snowfall was obtained by daily precipitation times daily $S_{\text {rat }}$.

In individual measurements, both random and systematic errors inevitably occur (Kuusisto, 1984). To minimize these errors, a quality control of meteorological data was automatically undertaken prior to the datasets being stored at the Russian Research Institute for Hydrometeorological Information - World Data Center (RIHMI-WDC) (Veselov, 2002) and the National Meteorological Information Center (NMIC) of the China Meteorological Administration (Ma and Qin, 2012). We implemented additional quality control using the following requirements: (1) to ensure snow depth stability, at a given location, a month with less than 15 days of snow depth measurements was deleted. (2) Stations with sudden and steep changes in snow depth were eliminated from the list. (3) The World Meteorological Organization's (WMO) common approach to calculate anomalies is based on a 30year normal climate period (IPCC, 2013). In this study, we use 1971-2000 as the normal period. To ensure data continuity, stations with less than 20-year data during the 19712000 period were excluded. (4) At each station, we eliminated data points that exceeded 2 standard deviations from their long-term (1971-2000) mean. After these four steps of snow depth quality control, we used data from 1814 stations to investigate the climatology and variability of snow depth over the Eurasian continent (Fig. 1 and Table 1).

We defined a snow year starting from 1 July of a current year through 30 June of the following year to capture the en- tire seasonal snow cycle. Procedures and techniques for measuring snow depth may have changed over the course of station history before the 1950s. Consequently, snow depth data may not be homogeneous in the time series over the period of the record. Fortunately, there was no change in the procedure and technique of snow depth measurements since 1965 in Russia and the other countries in this study (Bulygina et al., 2009). We chose to use snow depth data from 1966 to 2012. The following variables were calculated for each station.

1. Daily snow depth: we defined a snow cover day with snow depth equal to or greater than $0 \mathrm{~cm}$ according to the standard method for deriving monthly mean snow depth based on the WMO climatological products ( $\mathrm{Ma}$ and Qin, 2012). Daily snow depth is the original in situ measurements of snow depth.

2. Monthly mean snow depth: monthly mean snow depth was computed as an arithmetic sum of daily snow depth divided by the number of days with snow on the ground within each month.

3. Annual mean snow depth: annual mean snow depth was calculated as an arithmetic sum of monthly mean snow depth divided by the number of available snow months for each snow year.

4. Annual maximum snow depth: the annual maximum snow depth was defined as the maximum daily snow depth within each snow year.

5. Long-term mean monthly snow depth: it was averaged from each monthly mean snow depth over the 19712000 period. 


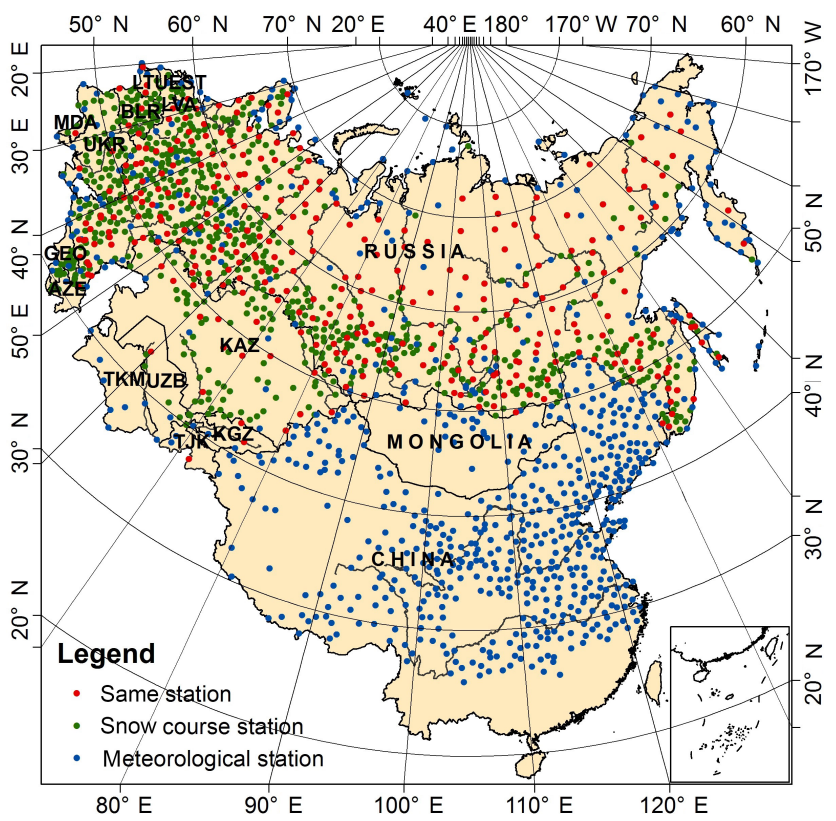

Figure 1. Geographical locations of meteorological stations and snow course survey across the Eurasian continent. The red circles represent stations where snow depth was measured at both meteorological stations and snow course surveys, the green circles show stations where snow depth was measured at snow surveys only, and the blue circles show stations where snow depth was measured at meteorological stations only. The abbreviations of countries represent Armenia (ARM), Azerbaijan (AZE), Belarus (BLR), Estonia (EST), Georgia (GEO), Kazakhstan (KAZ), Kyrgyzstan (KGZ), Lithuania (LTU), Latvia (LVA), Moldova (MDA), Tajikistan (TJK), Turkmenistan (TKM), Ukraine (UKR), and Uzbekistan (UZB).

6. Long-term mean annual snow depth: it was averaged from annual mean snow depths over the 1971-2000 period.

7. Long-term mean maximum snow depth: it was averaged from annual maximum snow depth over the 19712000 period.

Anomalies of monthly, annual mean, and annual maximum snow depth from their long-term (1971-2000) mean were calculated for each station across the Eurasian continent. Composite time series of monthly and annual anomalies were obtained by using all of the available station data across the study area.

Wavelet analysis was performed to reveal the long-term low-frequency variations in snow depth over the entire study area. We applied a discrete wavelet transform, excluded the high-frequency components, and then used the inverse transform to reconstruct the lower-frequency signal. Any trend analysis is an approximate and simple approach to obtain what has occurred on average during the study period. A linear trend analysis provides an average rate of this change. The linear trend analysis is also a useful approximation when systematic low-frequency variations emerge even though there is a nonlinearity (Folland and Karl, 2001; Groisman et al., 2006). The linear trend coefficient of the raw snow depth was calculated to represent the rate of change at each station. The Student $t$ test was used to assess statistical significance of the slope in the linear regression analysis and the partial correlation coefficients of snow depth, air temperature, and snowfall, and a confidence level above $95 \%$ was considered significant in our study. The Durbin-Watson test was used to detect serial correlation of data in the time series, and the Cochrane-Orcutt test was used to correct the serial correlation. Then, the serial correlations of the new data were rechecked and trends in the time series of the corrected data were recalculated. The methods and test results are described in the Appendix.

\section{Results}

\subsection{Climatology of snow depth}

Distributions of long-term mean annual snow depth indicate a strong latitudinal zonality. Generally, long-term mean annual snow depth increases with latitude northward across the Eurasian continent (Fig. 2). The maximum value of $109.3 \mathrm{~cm}$ is observed west of the Yenisei River (dark blue circle) (Fig. 2a). In contrast, the minimum values $(\sim 0.01 \mathrm{~cm})$ are observed in some areas south of the Yangtze River in China (small grey circles).

Long-term mean annual snow depth for most areas in Russia is $>10 \mathrm{~cm}$. Long-term mean annual snow depths are even greater in the northeastern part of European Russia, the Yenisei River basin, the Kamchatka Peninsula, and Sakhalin, with snow depths of $>40 \mathrm{~cm}$. Regions with the smallest longterm mean annual snow depth $(<5 \mathrm{~cm})$ are located in the eastern and western areas of the Caucasus Mountains. Longterm mean annual snow depth in the other areas of the former USSR is $\sim 2-10 \mathrm{~cm}$, but shallow long-term mean annual snow depths (no more than $1 \mathrm{~cm}$ ) are observed in some southern regions of central Asia. The long-term mean annual snow depth in the central Mongolian Plateau is lower than that in the northern areas with values of no more than $5 \mathrm{~cm}$. Long-term mean annual snow depth is $>3 \mathrm{~cm}$ in the northern part of the Tian Shan Mountains, Northeast China, and some regions of the southwestern TP. In the Altai Mountains and areas of the northeastern Inner Mongolia Plateau, long-term mean annual snow depths are $>5 \mathrm{~cm}$.

Long-term mean maximum snow depth (Fig. 2b) shows a similar spatial distribution pattern compared to the long-term mean snow depth pattern. The maximum value is approximately $200.2 \mathrm{~cm}$ in snow depth. For the majority of Russia, the long-term mean maximum snow depth is $>40 \mathrm{~cm}$. The regions with the long-term mean maximum snow depths of exceeding $80 \mathrm{~cm}$ are in the northeastern regions of European Russia, the northern part of the West Siberian Plain, the Yeni- 

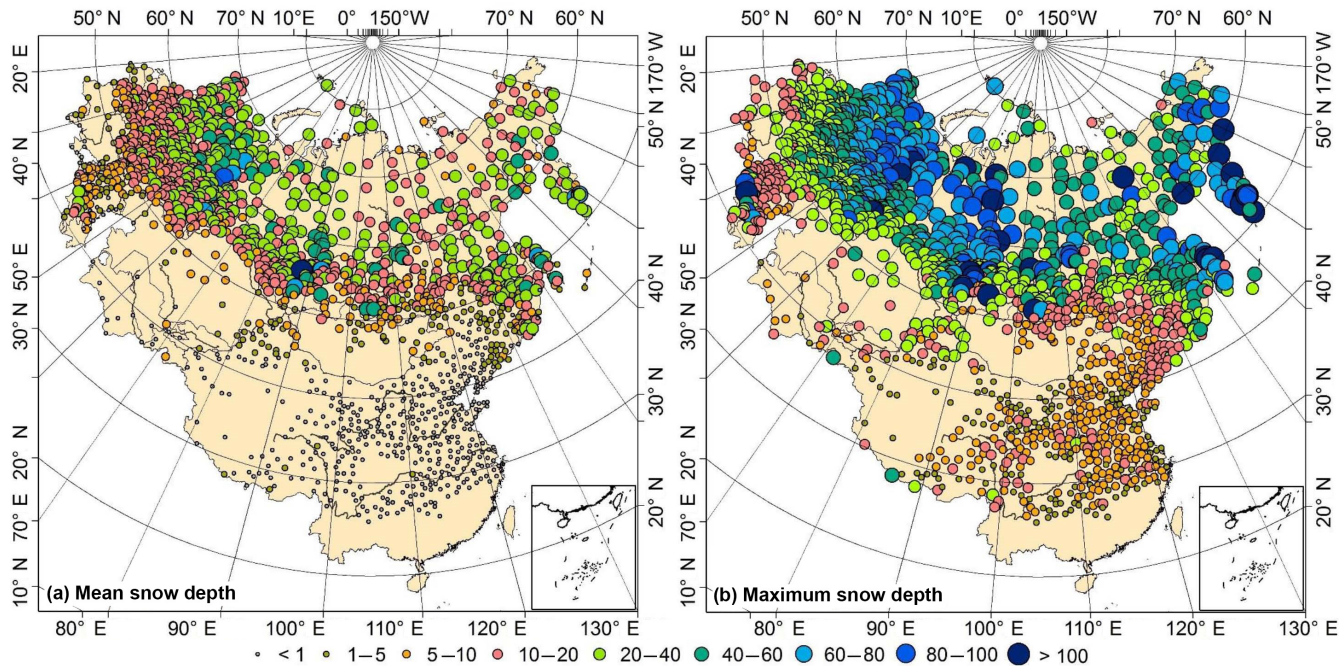

Figure 2. Long-term mean annual snow depth (a) and long-term mean maximum snow depth (b) across the Eurasian continent (cm) during the 1971-2000 period.
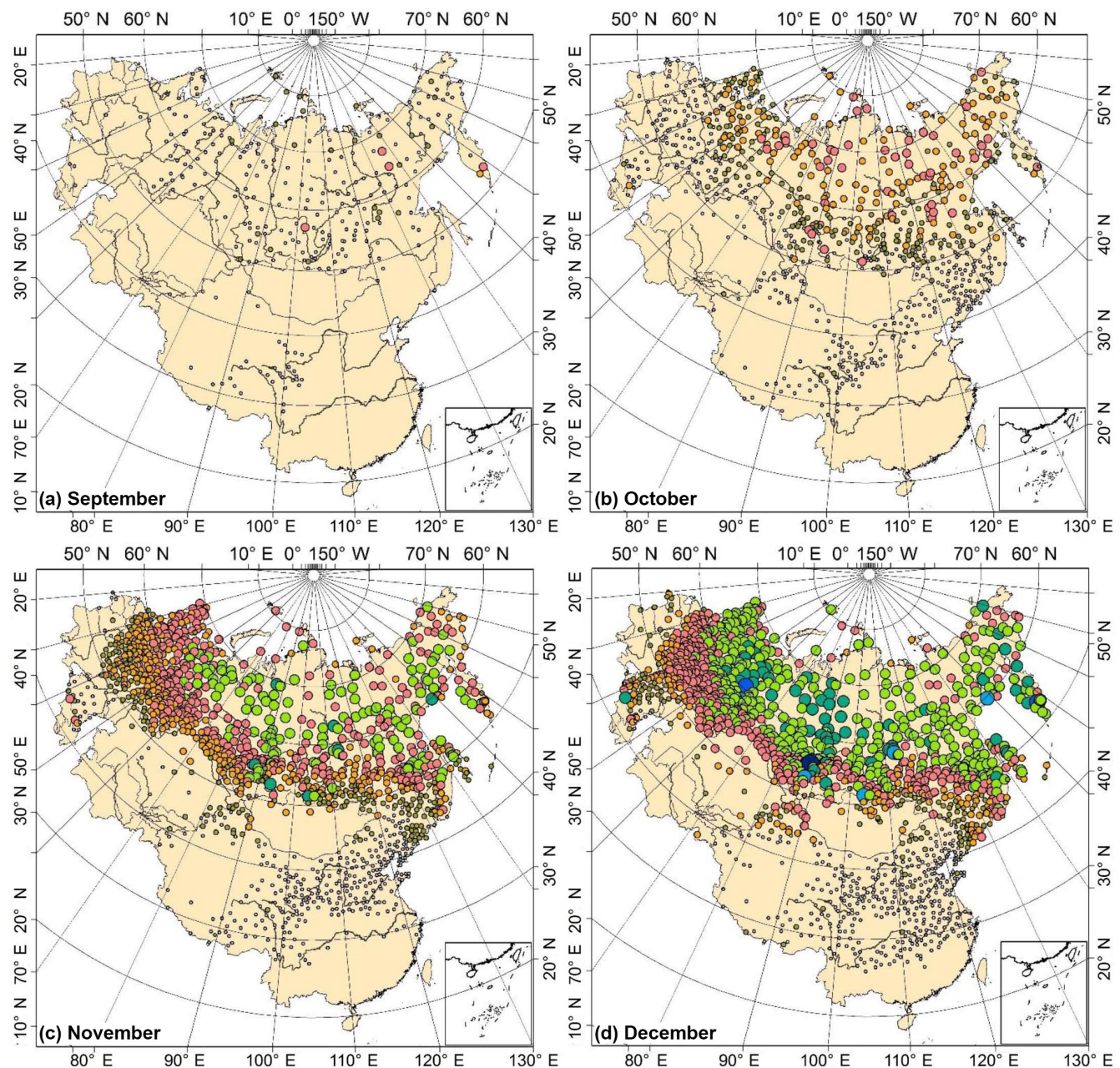

Figure 3. 

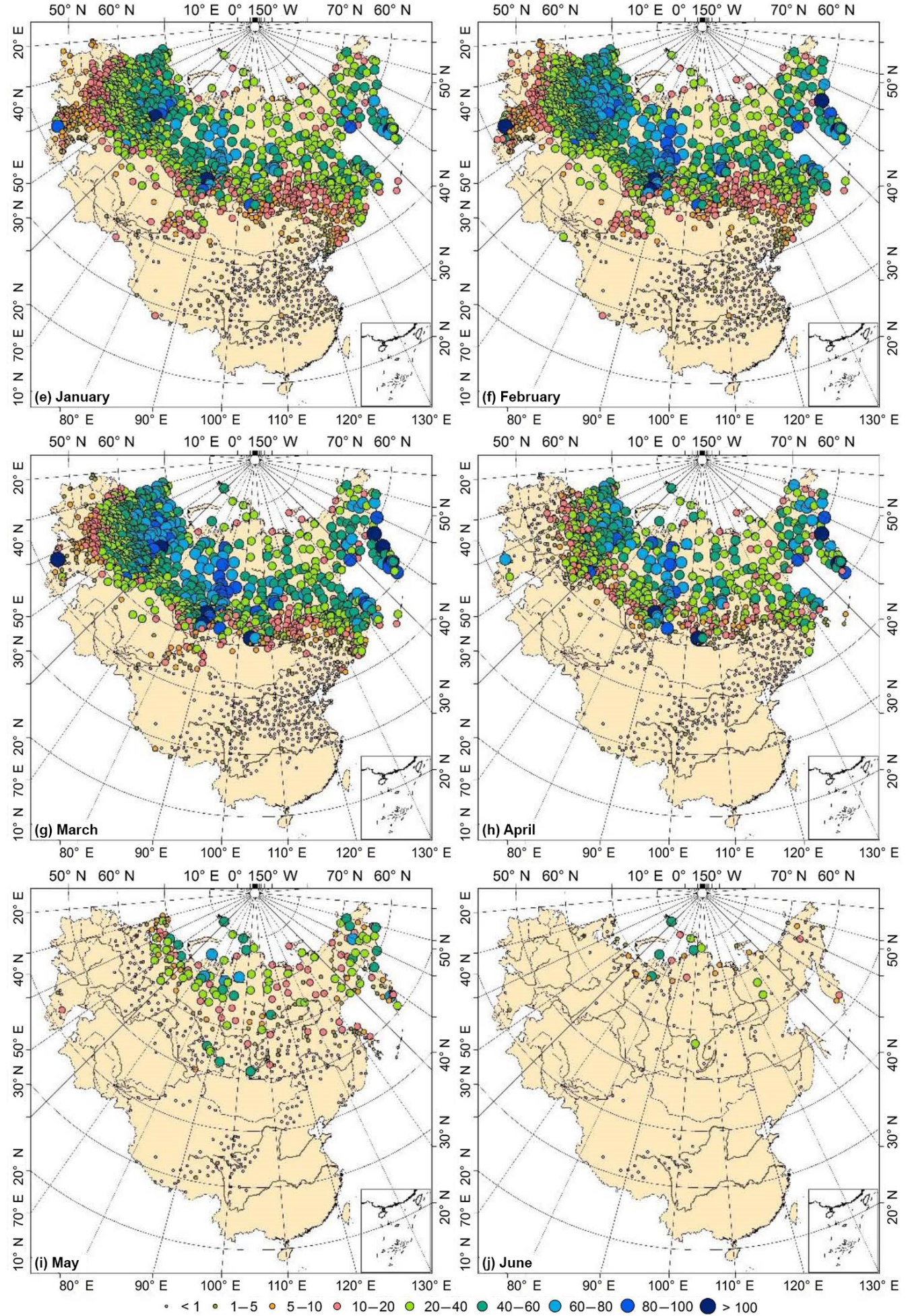

Figure 3. Long-term mean monthly snow depth (from September to June; in centimeters) across the Eurasian continent during the 19712000 period. (a) September. (b) October. (c) November. (d) December. (e) January. (f) February. (g) March. (h) April. (i) May. (j) June. 

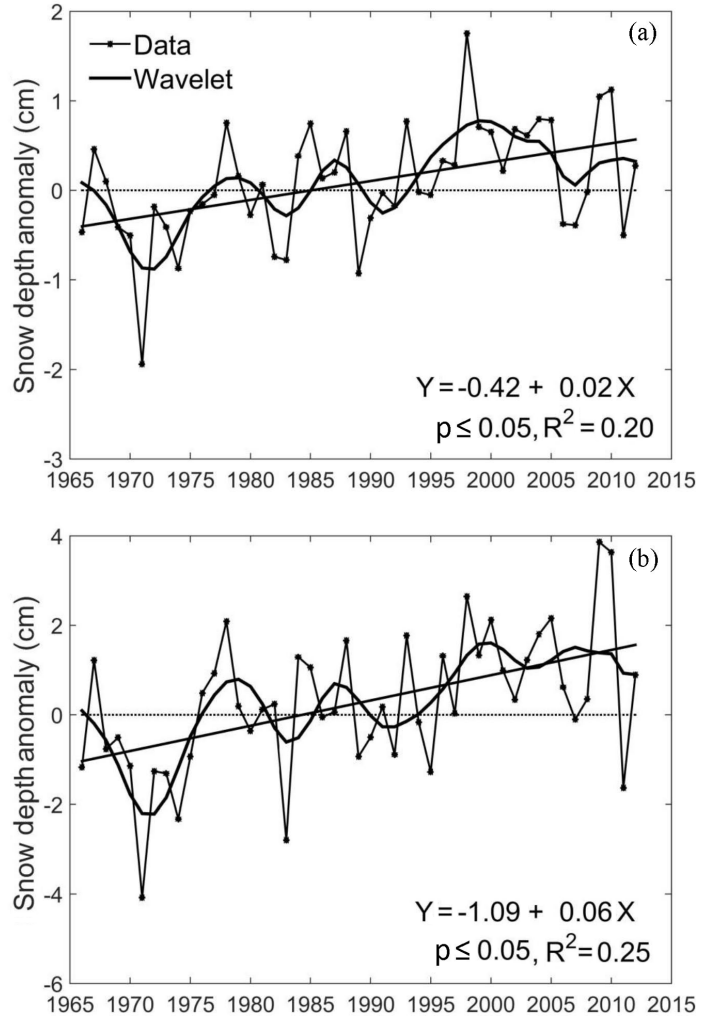

Figure 4. Composite of the anomalies of annual mean snow depth (a) and annual maximum snow depth (b) from 1966 through 2012 with respect to the 1971-2000 mean across the Eurasian continent. The composite anomaly was calculated by the sum of anomalies from all stations divided by the number of stations at a given year. The line with dots is the anomaly of snow depth. The thick curve represents the smoothed curve using wavelet analysis. The thick line presents a linear regression trend.

sei River basin, the Kamchatka Peninsula, and Sakhalin; in contrast, along the coast of the Caspian Sea, the long-term mean maximum snow depth is $<10 \mathrm{~cm}$. Most of the rest of the former USSR has a long-term mean maximum depth of $>10 \mathrm{~cm}$, except for some regions of the Ukraine and Uzbekistan. The long-term mean maximum snow depth is $>10 \mathrm{~cm}$ in northern Mongolia and decreases to $6-10 \mathrm{~cm}$ when moving south to central and eastern Mongolia. The long-term mean maximum snow depths are high over the northern part of the Xinjiang Autonomous Region of China, Northeast China, and eastern and southwestern TP, in which they are mostly greater than $10 \mathrm{~cm}$ and even greater than $20 \mathrm{~cm}$ in some areas. For the remaining regions of China, the longterm mean maximum snow depths are relatively small and mostly less than $10 \mathrm{~cm}$.

In the autumn months (September to November), the longterm mean monthly snow depth is shallow (Fig. 3a-c). Longterm mean monthly mean snow depth is $<20 \mathrm{~cm}$ in most areas of European Russia and south of Siberia but ranges from $\sim 20$ to $40 \mathrm{~cm}$ in northern Siberia and the Russian Far
East in November (Fig. 3c). Moving southward, the longterm mean monthly snow depth is less than $5 \mathrm{~cm}$ north of Mongolia and across China. From December to February, the long-term mean monthly snow depth increases and the snow cover extent expands significantly (Fig. 3d-f). Longterm mean monthly snow depth values are $>20 \mathrm{~cm}$ over the former USSR. Long-term mean monthly snow depth is still $<1 \mathrm{~cm}$ for the majority of China except the northern Xinjiang Autonomous Region of China, Northeast China, and southwestern T,P where long-term mean monthly snow depth exceeds $10 \mathrm{~cm}$. The long-term mean monthly snow depth is even more than $20 \mathrm{~cm}$ in some places of the Altai Mountains. In spring (March through May), snow cover areas decrease significantly (Fig. 3g-i), due mainly to snow disappearance in the majority of China. However, the long-term mean monthly snow depth still exceeds $20 \mathrm{~cm}$ in most areas of Russia. Snow cover areas and long-term mean monthly snow depth gradually decrease in April and May. Snow cover is observed only in Russia and in the TP in June (Fig. 3j).

\subsection{Variability of snow depth}

There are long-term significant increasing trends in both annual mean snow depth and annual maximum snow depth from 1966 to 2012 over the Eurasian continent. Annual mean snow depth increases at a rate of approximately $0.2 \mathrm{~cm} \mathrm{decade}^{-1}$, whereas annual maximum snow depth increases at a rate of approximately $0.6 \mathrm{~cm} \mathrm{decade}^{-1}$ (Fig. 4). Both annual mean snow depth and annual maximum snow depth exhibit a similar pattern of changes over the four decades, although the amplitude of annual maximum snow depth anomaly (approximately $\pm 2 \mathrm{~cm}$ ) is much larger than that of the annual mean snow depth anomaly (approximately $\pm 1 \mathrm{~cm}$ ). From the mid-1960s to the early 1970s, annual mean snow depth decreased slightly then increased until the early 2000s and then decreased sharply until 2012 (Fig. 4a). Annual maximum snow depth decreased by $2.5 \mathrm{~cm}$ from the mid-1960s through the early 1970s (Fig. 4b). There was a sharp increase of approximately 3 to $4 \mathrm{~cm}$ during the 1970s, then a large fluctuation without a significant trend from the late 1970 s to the early 1990 s, and finally another increase from the early 1990s through the early 2010s (Fig. 4b).

Monthly snow depth changes significantly across the Eurasian continent from 1966 through 2012 (Fig. 5). It decreases in October at a rate of approximately $-0.1 \mathrm{~cm} \mathrm{decade}{ }^{-1}$ (Fig. 5a), and there are no significant trends in November and December with large interannual variations (Fig. 5b and c). From January through April, it shows statistically increasing trends with rates between 0.3 and $0.6 \mathrm{~cm} \mathrm{decade}^{-1}$ (Fig. $5 \mathrm{~d}-\mathrm{g}$ ). Overall, monthly mean snow depth shows decrease in October, no trends with large interannual variability in November and December, and increasing trend from January to April.

Figure 6 shows the spatial distributions of linear trend coefficients of annual mean snow depth and annual maxi- 

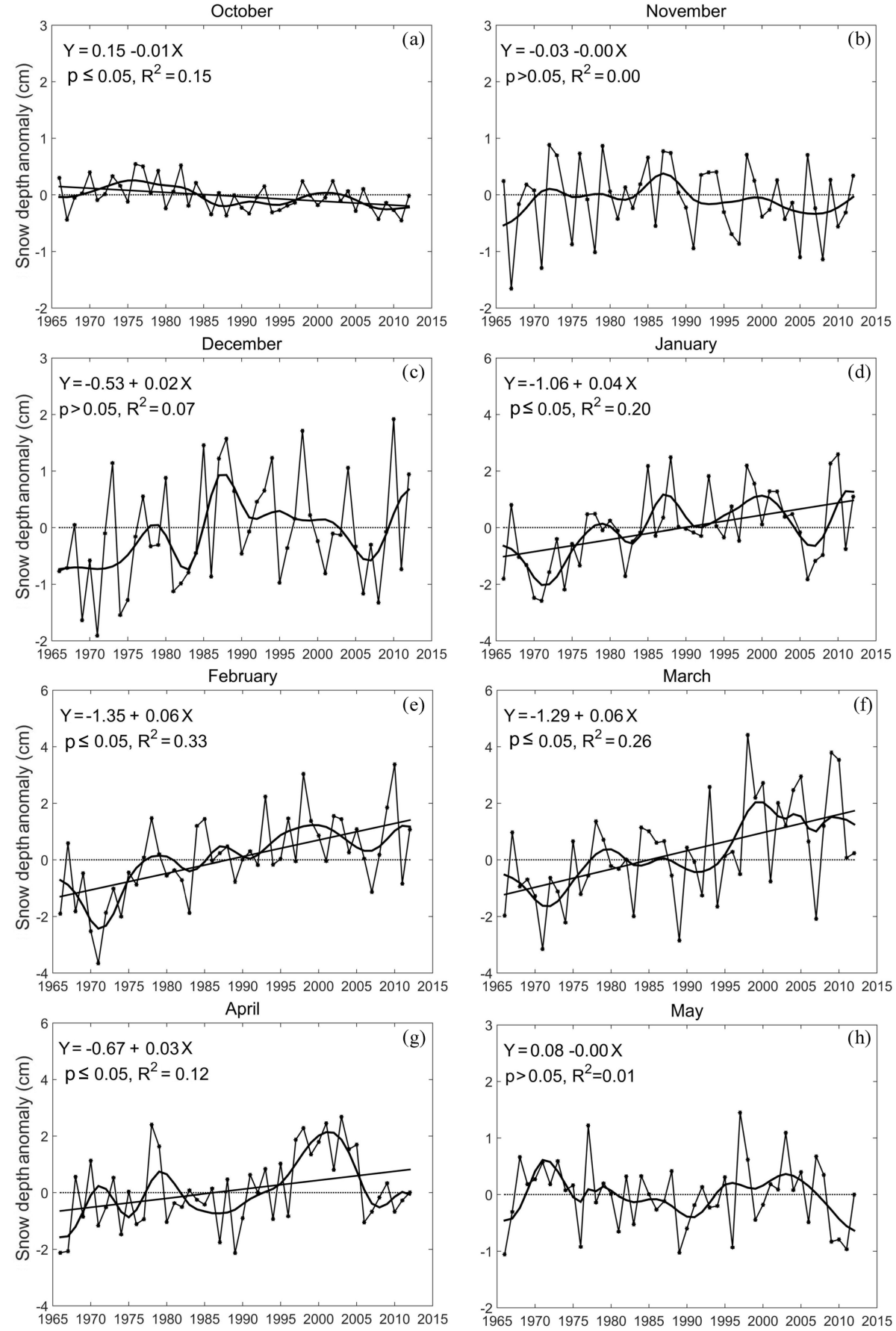

Figure 5. Composites of the anomalies of monthly mean snow depth (from October to May) from 1966 through 2012 with respect to the 1971-2000 mean across the Eurasian continent. The composite anomaly was calculated by the sum of anomalies from all stations divided by the number of stations at a given year. (a) October. (b) November. (c) December. (d) January. (e) February. (f) March. (g) April. (h) May. The line with dots is the anomaly of monthly mean snow depth. The thick curve represents the smoothed curve using wavelet analysis. The thick line presents a linear regression trend. Linear regression trend is only shown when the rate of change at the $95 \%$ level.

mum snow depth for each station during 1966-2012 with $p \leq 0.05$. The significant increasing trends (blue circles) of annual mean snow depth occur in European Russia, south of Siberia and the Russian Far East, the northern Xinjiang Au- tonomous Region of China, and Northeast China (Fig. 6a). In contrast, decreasing trends (red circles) are detected in western European Russia, some regions of Siberia, north of the Russian Far East, and the regions south of $40^{\circ} \mathrm{N}$ in China. 

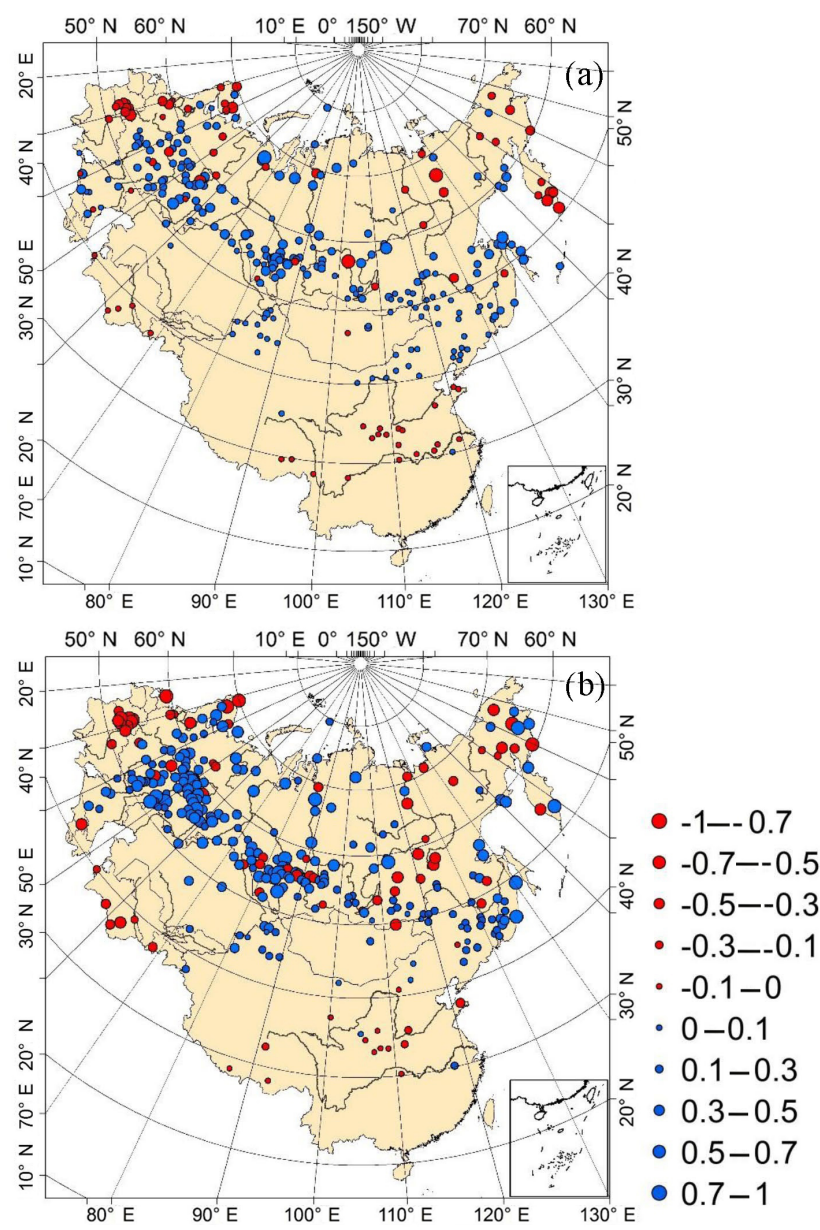

Figure 6. Spatial distribution of linear trend coefficients $\left(\mathrm{cm} \mathrm{yr}^{-1}\right)$ of annual mean snow depth (a) and annual maximum snow depth (b) for each station in 1966-2012. The rate of change at the $95 \%$ level is displayed. Red circles represent a decreasing trend, and blue circles represent an increasing trend.

Over the entire Eurasian continent, the most significant linear trends are observed in regions north of $50^{\circ} \mathrm{N}$, indicating that the increasing rate is greater in higher-latitude regions.

In October and November, there are few stations with significant increasing trends in monthly mean snow depth $(p \leq 0.05)$ (Fig. 7a and b). The increasing trends are mainly observed in most areas across the Eurasian continent in October although the magnitudes are generally small. Over November, the increasing trends only appear in Siberia and the Russian Far East, whereas decreasing trends occur over eastern European Russia, the southern West Siberian Plain, and the northeast Russian Far East.

In winter months (December-February), there is a gradual expansion in areas with increasing trends in monthly mean snow depth variation with $p \leq 0.05$ (Fig. 7c-e), and this mainly occur in eastern European Russia, southern Siberia, the northern Xinjiang Autonomous Region of China, and Northeast China. In contrast, significant decreasing trends are observed in northern and western European Russia and are scattered in Siberia, the northeast Russian Far East, and northern China.

From March to May, the number of stations with significant changes $(p \leq 0.05)$ in monthly mean snow depth decreases, especially in May because of snow melt (only 78 stations) (Fig. 7f-h). Changes in monthly mean snow depth are consistent with the trends in winter over the former USSR, but more stations with decreasing trends are found in southern Siberia. There are few stations with statistically significant trends across China; for these stations, monthly mean snow depths tend to decrease at most stations.

Overall, the data present significant increasing trends in annual mean snow depth, annual maximum snow depth, and monthly mean snow depth over Eurasia, especially in European Russia, south of Siberia, the northern Xinjiang Autonomous Region of China, and Northeast China. Compared with regions south of $50^{\circ} \mathrm{N}$, changes in snow depth are more significant over regions north of $50^{\circ} \mathrm{N}$.

\section{Discussion}

\subsection{Comparisons with previous results}

Studies on changes in snow depth have received much attention over different regions across Eurasian continent. The present study, for the first time, investigated changes in snow depth using ground-based data and information over the Eurasian continent as a whole. We found that climatology of long-term mean annual snow depth (1971-2000) was basically consistent with the results from Ma and Qin (2012) over China. In terms of changes in annual mean snow depth, both studies showed increase in annual mean snow depth but with slight difference in magnitude. This may be caused by using a different number of stations and covering different study periods. The long-term (1971-2000) mean annual snow depth from the present study was approximately 5$10 \mathrm{~cm}$ higher than the results from Kitaev et al. (2005) and Bulygina et al. (2011) over northern Eurasia. These discrepancies may result from differences in the time frame of data collection, the number of stations, calculation methods, and data quality control. For example, Kitaev et al. (2005) investigated historical changes in annual mean snow depth spanning 65 years from 1936 to 2000, while the present study covered 47 years from 1966 through 2012. We intentionally did not use the earlier (1936-1965) data due primarily to data quality. The earlier Russian snow depth data were discontinuous and did not meet the data quality control requirements used. Historical changes in the hydrometeorological station locations are also a critical reason for deleting many stations from the study. Based on results from the present study, we believe that snow depth data in the early years (prior to 1965) may be questionable and changes in snow depth prior to 1965 over Russia need further in-depth investigation. 

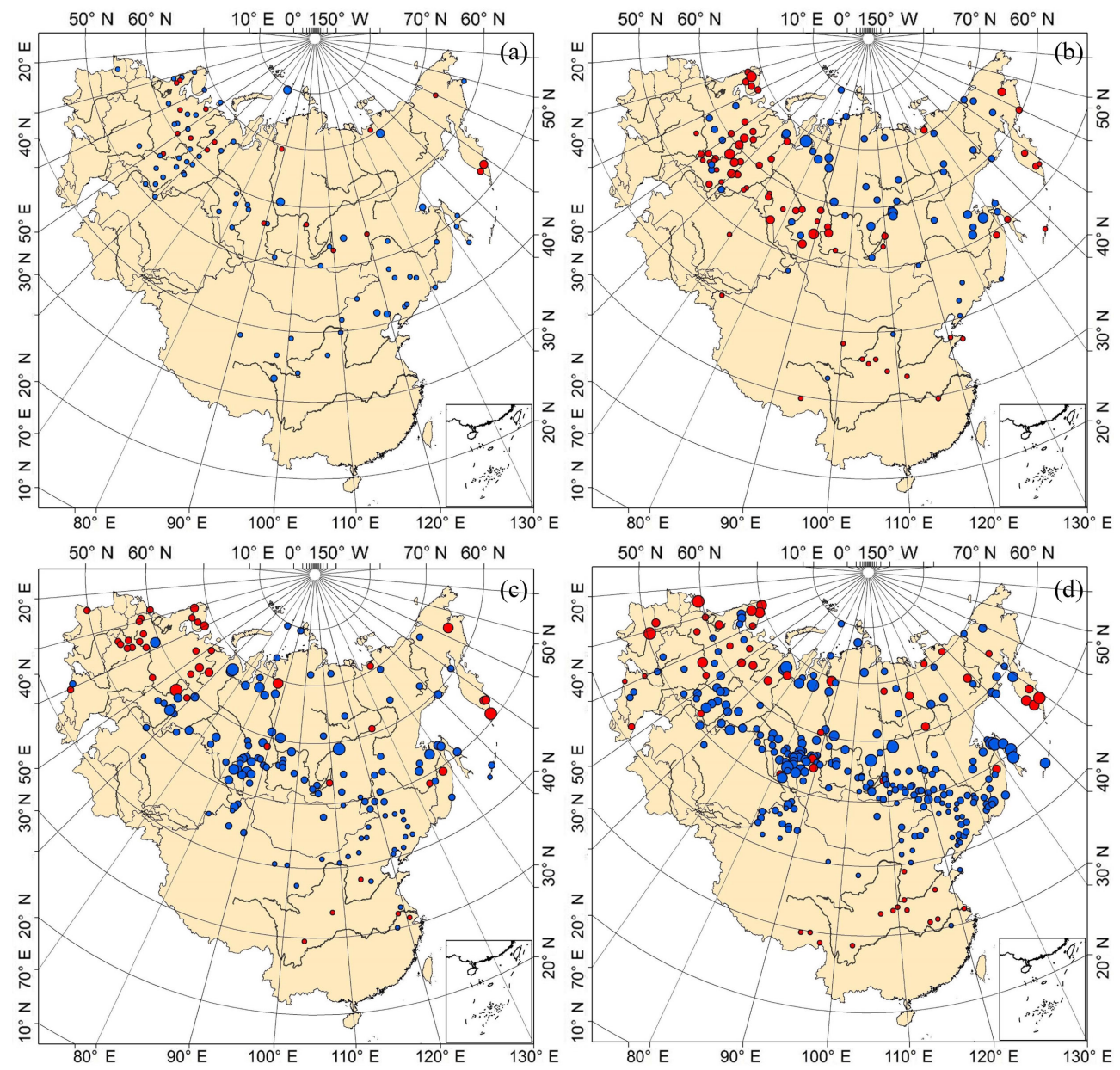

Figure 7.

Ye et al. (1998) found that historical winter mean snow depth increased in northern Russia $\left(1.86 \mathrm{~cm} \mathrm{yr}^{-1}\right)$ and decreased in southern Russia at a rate of $-0.23 \mathrm{~cm} \mathrm{yr}^{-1}$ during 1936-1983 (Ye et al., 1998). Results from the present study were essentially consistent with Ye et al. (1998) in northern Russia; however, we found winter monthly mean snow depth increased at a rate of $0.42 \mathrm{~cm} \mathrm{yr}^{-1}$ in southern Siberia during the period from 1966 to 2012. We believe that the difference is mainly due to the time periods covered by the two studies.

Liston and Hiemstra (2011) conducted snow depth assimilation using the SnowModel. Results from the SnowModel assimilations in general agree well with ground-based measurements. For example, both observations from our study and assimilations with the SnowModel (Liston and Hiemstra, 2011) indicated that the peak long-term mean annual snow depth occurred more in the western portion of northern Eurasia than the Russian Far East. The similar result may be primarily because the SnowModel input data included groundbased measured air temperature, precipitation, wind conditions, and in part snow depth. However, results from CMIP5 (Coupled Model Intercomparsion Project Phase 5; Terzago et al., 2014; Wei and Dong, 2015) overestimated snow depth over the TP and underestimated in forest regions. This implies that large uncertainties currently still exist in CMIP5 modeling snow depth.

\subsection{Impact of topography on snow depth}

Topography is an important factor affecting climatology of snow depth and the main reason accounting for snow depth data inhomogeneity (Grünewald and Lehning, 2011, 2013; Grünewald et al., 2014). To explore the effects of complex terrain on snow depth over Eurasia, we conducted a linear regression analysis of long-term mean annual snow depth with latitude, elevation, and continentality (Fig. 8). Longterm mean annual snow depth is positively correlated with latitude, i.e., generally increases with latitude (Fig. 8a). The increased rate is approximately $0.81 \mathrm{~cm}$ per $1^{\circ} \mathrm{N}$ across the Eurasian continent. A closer relationship between latitude and long-term mean annual snow depth is found in regions north of $40^{\circ} \mathrm{N}$, where snow cover is relatively stable with the 

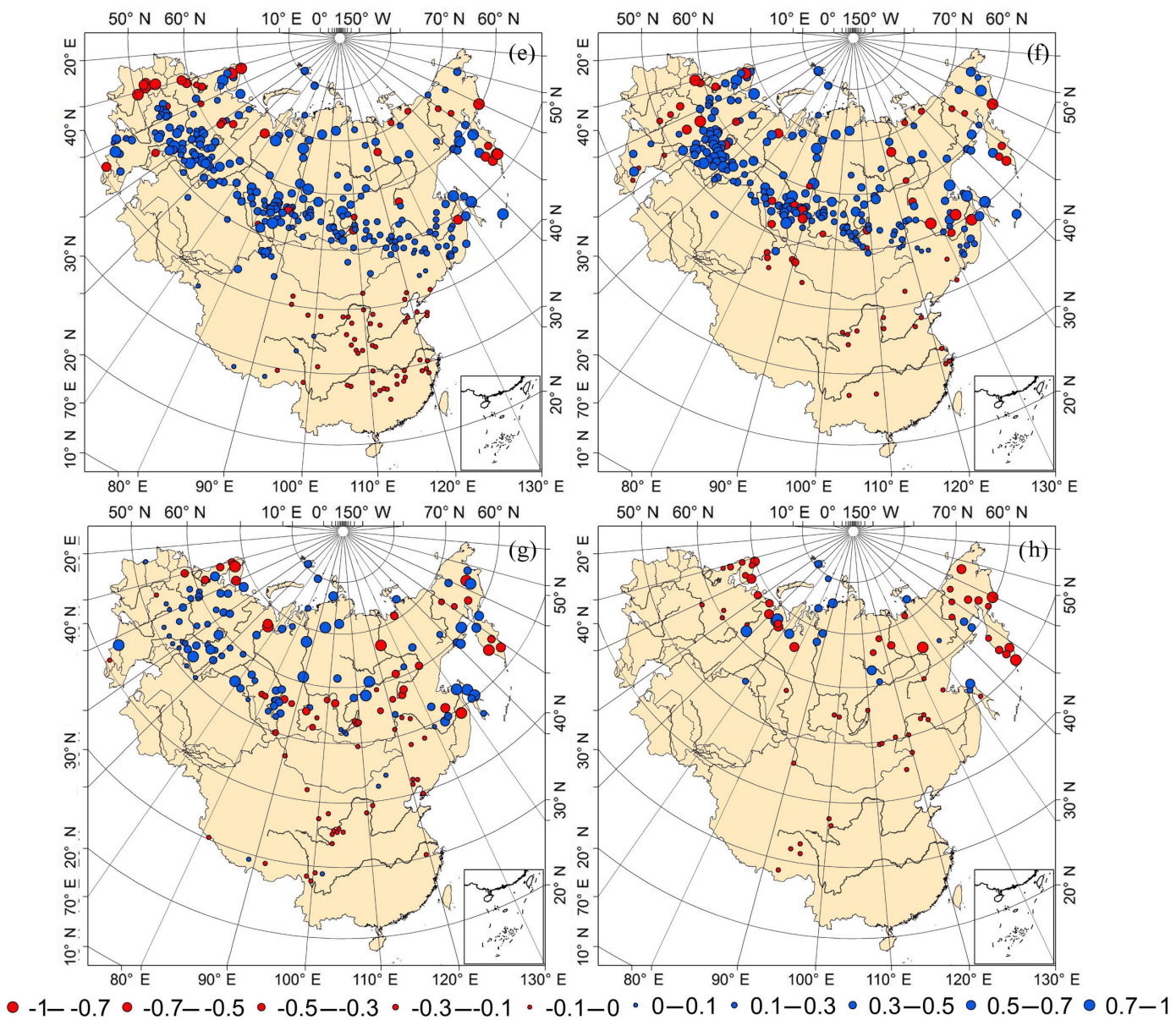

Figure 7. Spatial distributions of linear trend coefficients $\left(\mathrm{cm} \mathrm{yr}^{-1}\right)$ of monthly mean snow depth (from October to May) during 1966 to 2012. (a) October. (b) November. (c) December. (d) January. (e) February. (f) March. (g) April. (h) May. The rate of change at the $95 \%$ level is displayed. Red circles represent a decreasing trend, and blue circles represent an increasing trend.

number of annual mean continuous snow cover days at more than 30 (Zhang and Zhong, 2014).

Overall, there is a negative correlation between long-term mean annual snow depth and elevation across the Eurasian continent (Fig. 8b); with every $100 \mathrm{~m}$ increases in elevation, long-term mean annual snow depth decreases by $\sim 0.5 \mathrm{~cm}$ $(p \leq 0.05)$. In Fig. 8c, snow depths are averaged over $200 \mathrm{~m}$ elevation bands. Long-term mean annual snow depths are higher in the lower elevation bands (between 0 and $600 \mathrm{~m}$ ) across the former USSR (Fig. 8c). However, there are shallow long-term mean annual snow depths between 600 and $1000 \mathrm{~m}$ due mainly to forest effect. Long-term mean annual snow depths increase with elevation and reach the peak at $1600 \mathrm{~m}$. Long-term mean annual snow depths then show marked decrease in the highest elevation band (2600 $3000 \mathrm{~m})$. There are only two stations in this band (2600 $3000 \mathrm{~m}$ ) and long-term mean annual snow depths are very different between the two stations because of terrain and climate factors. In China, snow is deeper in three elevation bands: $200-1000,1600-1800$, and $2400-2600 \mathrm{~m}$. Greater snow depth is attributed to more snowfall and severe cold weather in these regions. An increasing trend with elevation is present above $2600 \mathrm{~m}$ on the TP.

Continentality is roughly a measure of distance from oceans. Continentality affects precipitation and thus determines snowfall rate and snow depth. Although there is a statistically significant positive relationship between long-term mean annual snow depth and continentality over the Eurasian continent, the goodness of fit is only $1 \%$ (Fig. 8d). This indicates that the continentality may not be an important driving factor of snow depth distribution compared to latitude and elevation over Eurasia, especially on the TP.

\subsection{Impact of climate factors on snow depth}

In addition to the terrain factors, variations in snow depth are closely related to climate variability. To examine the relationship between snow depth and climatic factors, we calculated the long-term mean snow depth, air temperature, and snowfall of 386 stations from November through March across the former USSR (Fig. 9). Long-term mean annual snow 

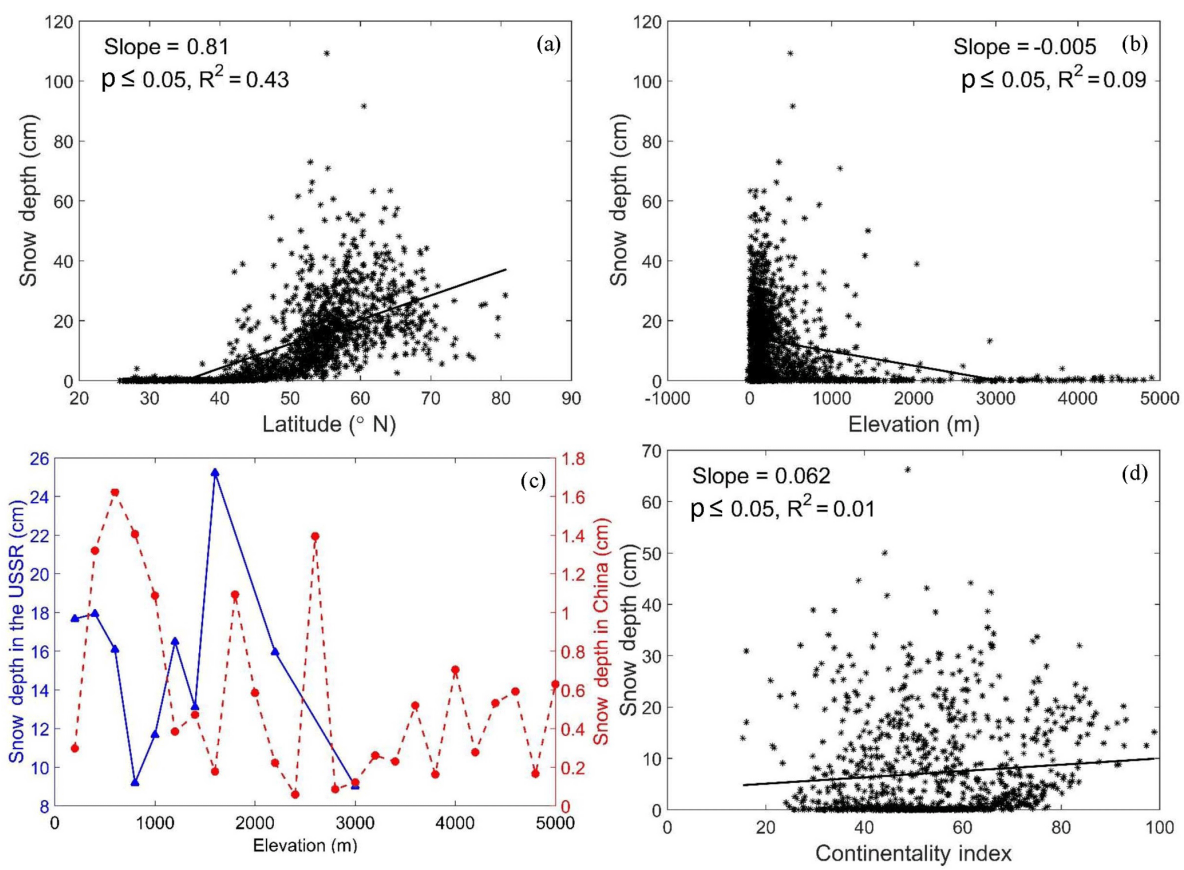

Figure 8. Relationship between long-term mean annual snow depth and latitude (a), elevation (b, c), and continentality (d) for all stations across the Eurasian continent during 1971-2000. Asterisks show the long-term mean annual snow depth at each station; the thick line is a linear regression trend.

depth significantly decreases with increasing air temperature $(p \leq 0.05)$ but the goodness of fit of the relationship is only $10 \%$ (Fig. 9a). Compared with air temperature, snowfall exhibits a strong relationship with long-term mean annual snow depth (Fig. 9b). The long-term mean annual snow depth is less than $40 \mathrm{~cm}$ at most stations with an accumulated snowfall of $<100 \mathrm{~mm}$ from November through March. Long-term mean annual snow depth increases with an increase in accumulated snowfall, and the thickest long-term mean annual snow depth of approximately $110 \mathrm{~cm}$ corresponds to a maximum cumulative snowfall of approximately $340 \mathrm{~mm}$.

Overall, the annual mean air temperature, snowfall, and snow depth display increasing trends from November to March during 1966 through 2009 (Fig. 10). This is because the increased precipitation falls as snow in cold areas where the increased temperature is still below freezing (Ye et al., 1998; Kitaev et al., 2005). Warmer air leads to a greater supply of moisture for snowfall and hence the snow depth still increases (Ye et al., 1998). Significant increasing snowfall can explain the sudden drop in bulk snow density from the mid-1990s through the early 2000s (Zhong et al., 2014): increasing snowfall should decrease the density of the surface snowpack, which lowered the bulk density of the snowpack. In addition, there are similar interannual variations in snowfall and heavy snowfall (heavy snowfall is defined as daily snowfall amount between 5 and $9.9 \mathrm{~mm}$ by the China Meteorological Administration; Scientific Knowledge, 2009). This indicates that extreme snowfall events may be the main cause of the increase in annual mean snow depth.

The partial correlation coefficients between snow depth, air temperature, and snowfall are calculated to discuss the spatial relationship among them (Fig. 11). A significant negative correlation $(p \leq 0.05)$ between long-term mean annual snow depth and air temperature is present in most areas of European Russia and southern Siberia (Fig. 11a). However, there is no statistically significant correlation among them in northern Siberia. This is because there is no obvious effect of increasing temperature on snow depth when the air temperature is below $0{ }^{\circ} \mathrm{C}$, which occurs in most areas of Siberia from November through March.

Compared with the previous studies (Fallot et al., 1997; Park et al., 2013), sensitivity of snow depth to air temperature and precipitation for each station show regional differences. The amount of snowfall can be affected by climate change and leads to differences in snow depth at different times (Ye et al., 1998; Kitaev et al., 2005; Ma and Qin, 2012). In addition to air temperature and precipitation, atmospheric circulation is a key factor affecting snowfall and snow depth change (Cohen, 2011; Zhao et al., 2013; Ye et al., 2015). Those factors above and related uncertainties may explain the regional and temporal differences in long-term mean snow depth and snow depth change.

Snow cover extent and snow cover duration have decreased in response to climate change (Bulygina et al., 2009; Brown and Robinson, 2011; IPCC, 2013; Xu et al., 2017) 

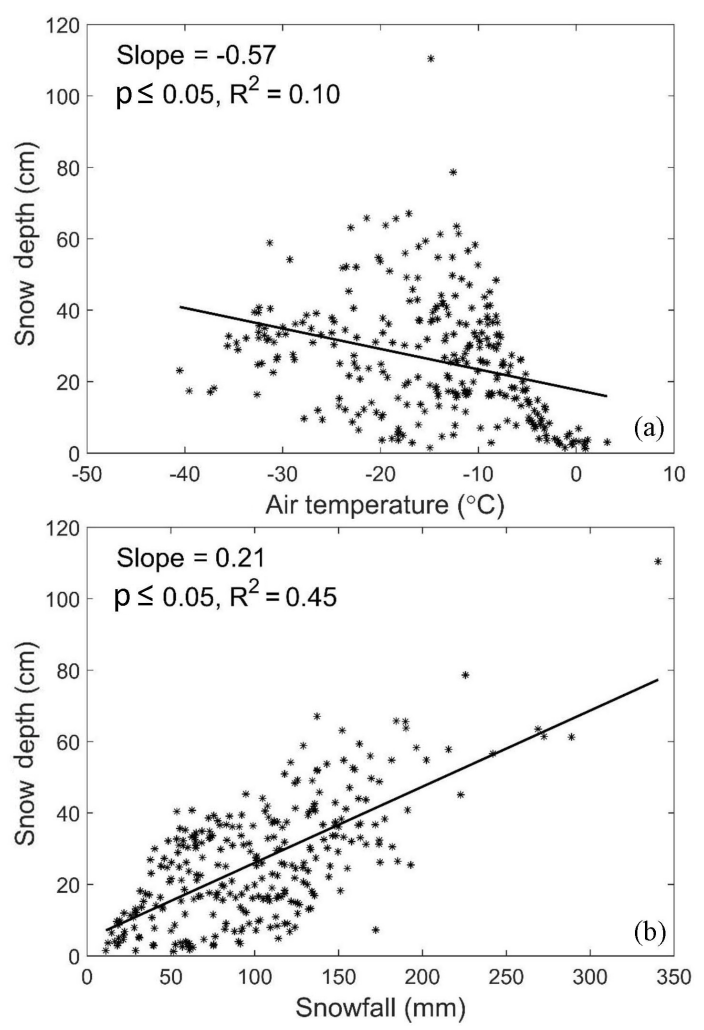

Figure 9. Relationship between long-term mean annual snow depth and air temperature (a) and between long-term mean annual snow depth and snowfall (b) from 386 stations from November through March during 1971-2000 over the USSR. The thick line is a linear regression trend.

but snow depth increases significantly with in situ data over Eurasia. The present study shows that there are similar interannual variations in annual mean snow depth and heavy snowfall, which implies that extreme snowfall may be the main reason for snow thickening.

\subsection{Potential effects of variations in snow depth}

Snow depth is an important factor for controlling the ground thermal regime (Goodrich, 1982; Zhang et al., 1996; Zhang, 2005; Ling and Zhang, 2005; Park et al., 2015). Studies have shown that thin snow cover resulted in a cooler soil surface, whereas thick snow cover led to a warmer soil surface (Kudryavtsev, 1992). Frauenfeld et al. (2004) indicated that the maximum snow depth by the end of winter had a significant influence on active layer depth in the following summer. Snow depth was responsible for $50 \%$ or more of the changes in soil temperature at a depth of $3.6 \mathrm{~m}$ in northeastern Siberia from 1901 to 2009 (Park et al., 2015). Results from the present study indicated that annual mean snow depth significantly decreased on the TP and increased in Siberia. Although it is not clear what the role (cooling or warming) of snow cover is on soil thermal region on the TP, the decrease in snow depth would reduce the warming effect, offsetting the increase in permafrost temperatures (Zhang, 2012). Over Siberia, increase in snow depth would further increase permafrost temperatures (Zhang et al., 2001; Zhang, 2005; Park et al., 2015), enhancing permafrost degradation over the region.

Snow cover has an important impact on the hydrological cycle (AMAP, 2011). Spring floods are generated by melting snow, and freshwater is derived from snowmelt in some snow-dominated basins (Barnett et al., 2005). Increasing snow depth may lead to frequent spring floods in northern Xinjiang and snow depth reduction can result in freshwater shortage on the TP. Furthermore, snow interacts with vegetation and in turn vegetation affects snow depth, redistribution, and the vertical profile in forests or shrubs (Hedstrom and Pimeroy, 1998; Pomeroy et al., 2006). Snow also influences plant growth: snow depth with more water content will increase soil moisture and promote vegetation productivity (Peng et al., 2010). Therefore, increasing snow depths could contribute to forest growth in northern Eurasia and Northeast China.

\section{Conclusions}

In this study, daily snow depth and snow course data from 1814 stations were used to investigate spatial and temporal changes in annual mean snow depth and annual maximum snow depth over the Eurasian continent for the period from 1966 to 2012. Our results demonstrate that greater longterm mean annual snow depth was observed in northeastern European Russia, the Yenisei River basin, the Kamchatka Peninsula, and Sakhalin. In contrast, the shallowest longterm mean annual snow depths were recorded in China, except for the northern Xinjiang Autonomous Region of China, Northeast China, and some regions of the southwestern TP.

There were statistically significant trends in variations in long-term annual mean snow depth over the entire Eurasian continent. A similar increasing pattern of changes was exhibited in both long-term annual mean snow depth and longterm maximum mean snow depth, although the amplitude of the long-term maximum mean snow depth anomaly was much larger than the equivalent value for the long-term annual mean snow depth. Monthly mean snow depth in autumn presented a decreasing trend, whereas there were increasing trends during winter and spring, especially during the period of the mid-1980s through the 2000s.

Significant increasing trends in annual mean snow depth were detected in the eastern regions of European Russia, southern Siberia, the Russian Far East, the northern areas of the Xinjiang Autonomous Region of China, and Northeast China. Decreasing linear trends were observed in most western areas of European Russia, some regions of southern Siberia, the northeastern Russian Far East, and most areas in the southern $40^{\circ} \mathrm{N}$ across China. 

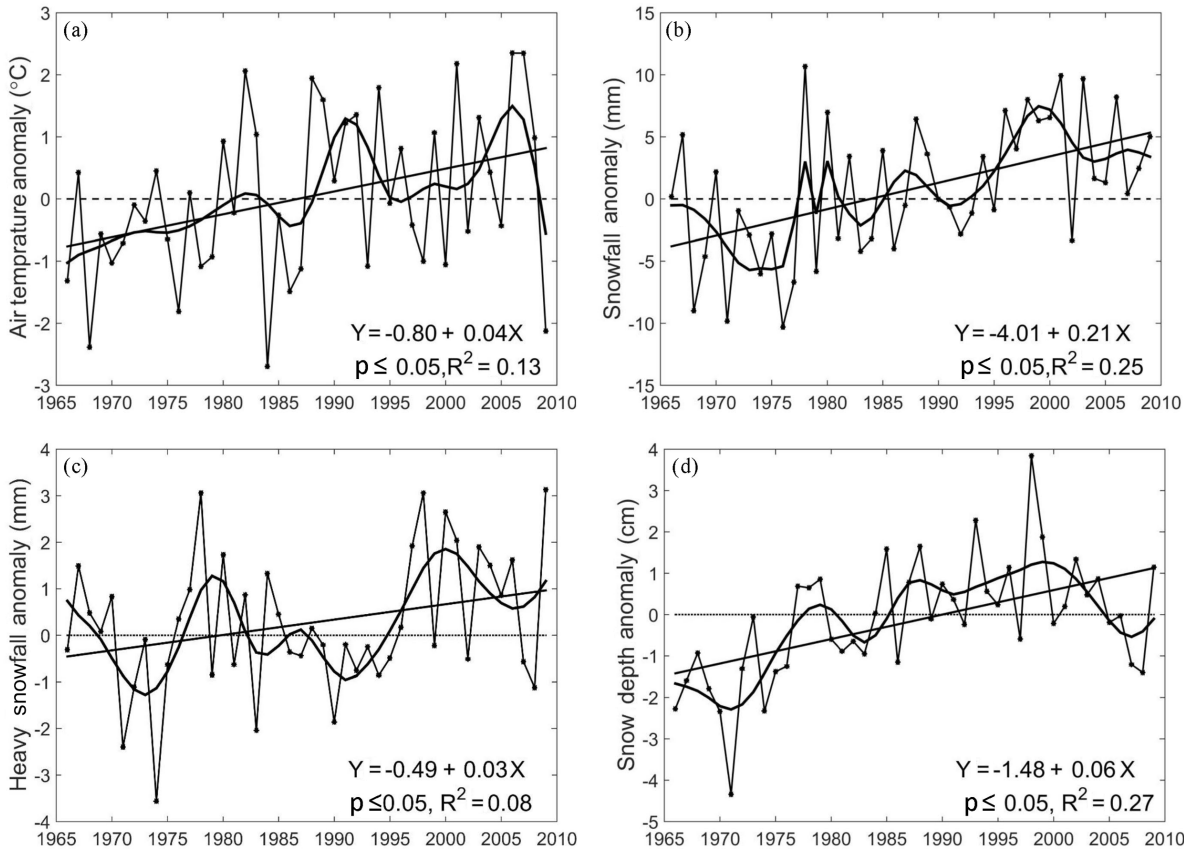

Figure 10. Composite of the anomalies of annual mean air temperature (a), annual snowfall (b), annual heavy snowfall (c), and annual mean snow depth (d) from November through March during 1966-2009 with respect to the 1971-2000 mean across the former USSR. The composite anomaly was calculated by the sum of anomalies from all stations divided by the number of stations at a given year. The line with dots is the composite of the annual means. The thick curve represents the smoothed curve using wavelet analysis. The thick line presents a linear regression trend.

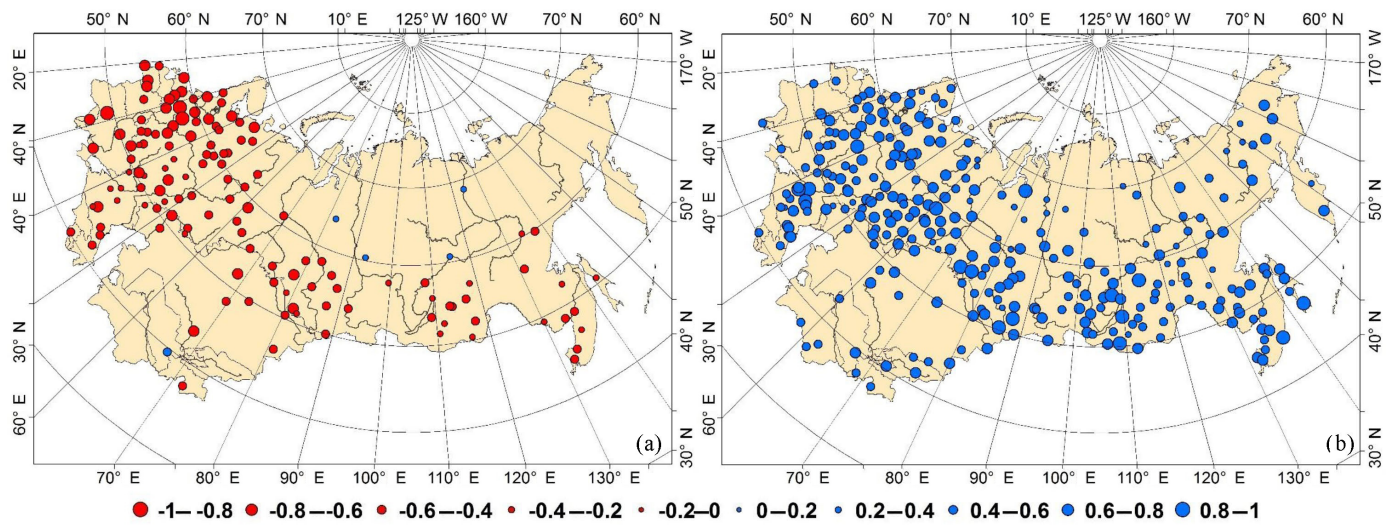

Figure 11. Spatial distributions of partial correlation coefficients between long-term mean annual snow depth and air temperature (a) and between long-term mean annual snow depth and snowfall (b) from November through March across the former USSR. The coefficients reaching to the $95 \%$ confidence level are displayed. Red circles represent a negative relationship, and blue circles indicate a positive relationship.

Compared with elevation, latitude played a more important role in snow depth climatology. Variations in annual mean snow depth were explained by air temperature and snowfall in most areas of European Russia and some regions of southern Siberia; however, snowfall, especially heavy snowfall, was the main driving force of the variance of annual mean snow depth in the former USSR.
Data availability. The dataset has been added as a Supplement. 


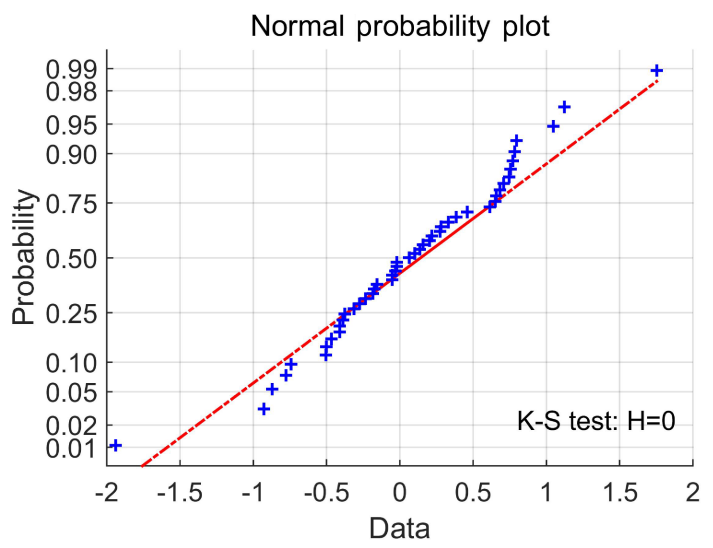

Figure A1. Normal distribution of annual mean snow depth for all stations by Kolmogorov-Smirnov test.

\section{Appendix A: Analysis of serial correlation}

In this research, the Kolmogorov-Smirnov test was used to determine whether snow depth data followed a normal distribution. The results showed that all station data followed a normal distribution (such as annual mean snow depth for all stations; Fig. A1). We used ordinary linear regression (OLR) to detect trends in changes in snow depth. Failure to consider the serial correlation of data could lead to erroneous results when detecting the trends in a time series of snow depth, which is mainly because the probability of detecting false trends would be increased (Weatherhead et al., 1998; Storch, 1999; Khaliq et al., 2009). To avoid this situation, we used the Durbin-Watson test to check the serial correlation (Neter et al., 1989; Tao et al., 2008):

$d=\frac{\sum_{t=2}^{n}\left(e_{t}-e_{t-1}\right)^{2}}{\sum_{t=1}^{n} e_{t}^{2}}$

where $e_{t}$ was the residual estimated by the OLR, and $t$ was the number of observations. $d_{1}$ was the lower critical value, and $d_{\mathrm{u}}$ was the upper critical value, which could be obtained through the Durbin-Watson statistic table. If $d_{\mathrm{u}} \leq d \leq 4-d_{\mathrm{u}}$, a serial correlation was absent; if $d \leq d_{1}$ or $d \geq 4-d_{1}$, a serial correlation was present.

We used the Cochrane-Orcutt method to correct the variable if the serial correlation was present (Neter et al., 1989; Tao et al., 2008):

$X_{t}^{\prime}=X_{t}-\rho X_{t-1}$,

$Y_{t}^{\prime}=Y_{t}-\rho Y_{t-1}$,

where $X^{\prime}$ was the corrected year, $Y^{\prime}$ was the corrected anomaly in time series of snow depth for each station in this research, and the autocorrelation coefficient $\rho$ was replaced by its estimate value $r$ :
Table A1. Trends in snow depths with the Durbin-Watson test across Eurasia during 1966-2012.

\begin{tabular}{lcccrc}
\hline & $d_{1}$ & $d_{u}$ & $d$ & Slope* $^{*}$ & $p^{*}$ \\
\hline Mean & 1.3034 & 1.3871 & 1.6435 & 0.02 & 0.0016 \\
Maximum & 1.3034 & 1.3871 & 1.8824 & 0.06 & 0.0004 \\
October & 1.3034 & 1.3871 & 2.1377 & -0.01 & 0.0069 \\
November & 1.4872 & 1.5739 & 2.3667 & 0.00 & 0.7408 \\
December & 1.4872 & 1.5739 & 1.9684 & 0.02 & 0.0793 \\
January & 1.3034 & 1.3871 & 1.6326 & 0.04 & 0.0014 \\
February & 1.3034 & 1.3871 & 1.8469 & 0.06 & 0.0000 \\
March & 1.3034 & 1.3871 & 1.9874 & 0.06 & 0.0003 \\
April & 1.3034 & 1.3871 & 1.6754 & 0.03 & 0.0187 \\
May & 1.4872 & 1.5739 & 2.0703 & 0.00 & 0.5811 \\
\hline
\end{tabular}

* Slope is the trend of changes in snow depth; the unit is $\mathrm{cm} \mathrm{yr}^{-1} \cdot p$ is the confidence level.

$r=\frac{\sum_{t-2}^{n} e_{t-1} e_{t}}{\sum_{t-2}^{n} e_{t-1}^{2}}$.

Then, the Durbin-Watson test was used to check the serial correlation of the new snow depth anomalies and recalculate the trends in the time series of new data.

The Durbin-Watson test results show that there were no serial correlations in the interannual trends in annual mean snow depth, maximum snow depth, and monthly mean snow depth for all of the composite data $\left(d_{\mathrm{u}} \leq d \leq 4-d_{\mathrm{u}}\right)$ (Table A1). However, the serial correlation was present in some stations when we calculated the linear trend of annual mean snow depth, maximum depth, and monthly mean snow depth for each station. The percentage of the stations with a serial correlation for annual mean snow depth and maximum depth were 18 and $21 \%$, respectively. In the monthly test, the smallest proportion appeared in October at approximately $11 \%$; the largest percentage of these stations for all of the stations was found in February and was up to $21 \%$. Then, the Cochrane-Orcutt method was used to correct the variables and re-estimated the trends in long-term mean snow depth for these station (Figs. 6-7 in the text). Using the Dikson site $\left(73.5^{\circ} \mathrm{N}, 80.4^{\circ} \mathrm{E} ; 42 \mathrm{~m}\right.$ a.s.l. $)$ as an example, the serial correlation was present when the trend in annual mean snow depth was calculated. Compared with the corrected result, the variance of the previous OLR statistic was overestimated, and annual mean snow depth increased at the rate of $0.113 \mathrm{~cm} \mathrm{yr}^{-1}$ (Table A2). The corrected result indicated that the variation of interannual mean snow depth was not significant $\left(P^{\prime}=0.05\right)$. The serial correlation cannot be ignored for detecting trends in a time series of snow cover variables, which possibly invalidates the statistical test on slopes if this variable is not dealt with. 
Table A2. Trends in annual mean snow depth with the Durbin-Watson test for the Dikson site during 1966-2012.

\begin{tabular}{lcccccccccc}
\hline ID & $d_{1}$ & $d_{u}$ & $d$ & Slope & $p$ & $d_{1}^{\prime}$ & $d_{u}^{\prime}$ & $d^{\prime}$ & Slope $^{*}$ & $p^{\prime *}$ \\
\hline 20674 & 1.3034 & 1.3871 & 1.2856 & 0.113 & 0.016 & 1.4872 & 1.5739 & 2.0249 & 0.0942 & 0.055 \\
\hline
\end{tabular}

* Slope ${ }^{\prime}$ is the corrected trend of changes in snow depth; the unit is $\mathrm{cm} \mathrm{yr}^{-1} \cdot p^{\prime}$ is the corrected confidence level. 


\section{The Supplement related to this article is available online at https://doi.org/10.5194/tc-12-227-2018-supplement.}

Competing interests. The authors declare that they have no conflict of interest.

Acknowledgements. We express our gratitude to the researchers who assembled and digitized the snow depth data at meteorological stations and snow surveys across the Eurasian continent over a period of $>40$ years. This work was funded by the National Key Scientific Research Program of China (2013CBA01802), the Open Foundation from the State Key Laboratory of Cryospheric Sciences (SKLCS-OP-2016-12), the Project for Incubation of Specialists in Glaciology and Geocryology of the National Natural Science Foundation of China (J1210003/J0109), and the Foundation for Excellent Youth Scholar of Cold and Arid Research Environmental and Engineering Research Institute, Chinese Academy of Sciences.

Edited by: Guillaume Chambon

Reviewed by: three anonymous referees

\section{References}

AMAP: Snow, Water, Ice and Permafrost in the Arctic (SWIPA), Arctic Monitoring and Assessment Programme (AMAP), Oslo, Norway, 553 pp., 2011.

Armstrong, R. L.: Historical Soviet daily snow depth, version 2 (HSDSD), CD-ROM, National Snow and Ice Data Center, Boulder, Colorado, 2001.

Armstrong, R. L. and Brown, R.: Introduction, in: Snow and climate: Physical processes, surface energy exchange and modeling, edited by: $\quad$ R. L. Armstrong, and Brun, E., Cambridge University Press, Cambridge, UK, 1-11, 2008.

Barnett, T. P., Adam, J. C., and Letternmaier, D. P.: Potential impact of a warming climate on water availability in snow-dominated regions, Nature, 438, 303-309, https://doi.org/10.1038/nature04141, 2005.

Brasnett, B.: A global analysis of snow depth for numerical weather prediction, J. Appl. Meteorol., 38, 726-740, 1999.

Brown, R. D.: Northern Hemisphere snow cover variability and change, 1915-97, J. Climate, 13, 2339-2355, https://doi.org/10.1175/15200442(2000)013<2339:NHSCVA>2.0.CO;2, 2000.

Brown, R. D. and Goodison, B. E.: Interannual variability in reconstructed Canadian snow cover, 1915-1992, J. Climate, 9, 1299-1318, https://doi.org/10.1175/15200442(1996)009<1299:IVIRCS>2.0.CO;2, 1996.

Brown, R. D. and Robinson, D. A.: Northern Hemisphere spring snow cover variability and change over 1922-2010 including an assessment of uncertainty, The Cryosphere, 5, 219-229, https://doi.org/10.5194/tc-5-219-2011, 2011.

Bühler, Y., Adams, M. S., Bösch, R., and Stoffel, A.: Mapping snow depth in alpine terrain with unmanned aerial systerms (UASs): potential and limitations, The Cryosphere, 10, 1075-1088, https://doi.org/10.5194/tc-10-1075-2016, 2016.
Bulygina, O. N., Razuvaev, V. N., and Korshunova, N. N.: Changes in snow cover over Northern Eurasia in the last few decades, Environ. Res. Lett., 4, 045026, https://doi.org/10.1088/17489326/4/4/045026, 2009.

Bulygina, O. N., Groisman, P. Y., Razuvaev, V. N., and Korshunova, N. N.: Changes in snow cover characteristics over Northern Eurasia since 1966, Environ. Res. Lett., 6, 045204, https://doi.org/10.1088/1748-9326/6/4/045204, 2011.

Callaghan, T. V., Johansson, M., Brown, R. D., Groisman, P. Y., Labba, N., and Radionov, V.: The changing face of Arctic snow cover: A synthesis of observed and projected changes, Ambio, 40, 17-31, https://doi.org/10.1007/s13280-011-0212-y, 2011.

Che, T., Dai, L., Zheng, X., Li, X., and Zhao, K.: Estimation of snow depth from passive microwave brightness temperature data in forest regions of northeast China, Remote Sens. Environ., 183, 334-349, https://doi.org/10.1016/j.rse.2016.06.005, 2016.

Cohen, J. L.: Eurasian snow cover variability and links with stratosphere-troposphere coupling and their potential use in seasonal to decadal climate predictions, in: Climate test bed joint seminar series, NCEP, US National Oceanic and Atmospheric Administration, Camp Springs, Maryland, 6 pp., 2011.

Derksen, C., Walker, A., and Goodison, B.: A comparison of 18 winter seasons of in situ and passive microwave-derived snow water equivalent estimates in Western Canada, Remote Sens. Environ., 88, 271-282, https://doi.org/10.1016/j.rse.2003.07.003, 2003.

Dickerson-Lange, S. E., Lutz, J. A., Martin, K. A., Raleigh, M. S., Gersonde, R., and Lundquist, J. D.: Evaluating observational methods to quantify snow duration under diverse forest canopies, Water Resour. Res., 51, 1203-1224, https://doi.org/10.1002/2014WR015744, 2015.

Dressler, K. A., Leavesley, G. H., Bales, R. C., and Fassnacht, S. R.: Evaluation of gridded snow water equivalent and satellite snow cover products for mountain basins in a hydrologic model, Hydrol. Process., 20, 673-688, https://doi.org/10.1002/hyp.6130, 2006.

Fallot, J., Barry, B. G., and Hoogstrate, D.: Variations of mean cold season temperature, precipitation and snow depths during the last 100 years in the former Soviet Union (FSU), Hydrolog. Sci. J., 42, 301-327, https://doi.org/10.1080/02626669709492031, 1997.

Folland, C. K. and Karl, T. R.: Observed climate variability and change, in: Climate Change 2001: The Scientific Basis, edited by: Houghton, J. T., Ding, Y., Griggs, D. J., Noguer, M., Linden P. J., Dai, X., Maskell, K., and Johnson, C. A., Cambridge University Press, Cambridge, UK, 99-181, 2001.

Foster, J. L., Chang, A. T. C., and Hall, D. K.: Comparison of snow mass estimates from a prototype passive microwave snow algorithm, Remote Sens. Environ., 62, 132-142, https://doi.org/10.1016/S0034-4257(97)00085-0, 1997.

Frauenfeld, O. W., Zhang, T., and Barry, R. G.: Interdecadal changes in seasonal freeze and thaw depth in Russia, J. Geophys. Res., 109, D05101, https://doi.org/10.1029/2003JD004245, 2004.

Goodrich, L. E.: The influence of snow cover on the ground thermal regime, Can. Geotech. J., 19, 421-432, https://doi.org/10.1139/t82-047, 1982.

Grippaa, M., Mognarda, N., Le Toana, T., and Josberger, E. G.: Siberia snow depth climatology derived from SSM/I data using a 
combined dynamic and static algorithm, Remote Sens. Environ., 93, 30-41, https://doi.org/10.1016/j.rse.2004.06.012, 2004.

Groisman, P., Knight, R., Razuvaev, V., Bulygina, O., and Karl, T.: State of the Ground: Climatology and Changes during the Past 69 Years over Northern Eurasia for a Rarely Used Measure of Snow Cover and Frozen Land, J. Climate, 19, 4933-4955, https://doi.org/10.1175/JCLI3925.1, 2006.

Grünewald, T. and Lehning, M.: Altitudinal dependency of snow amounts in two small alpine catchments: can catchment-wide snow amounts be estimated via single snow or precipitation stations?, Ann. Glaciol., 52, 153-158, https://doi.org/10.3189/172756411797252248, 2011.

Grünewald, T. and Lehning, M.: Can a point measurement represent the snow depth in its vicinity? A comparison of areal snow depth measurements with selected index sites, Proceedings of the International Snow Science Workshop, 7-11 October 2013, Grenoble, France, 69-72, 2013.

Grünewald, T., Bühler, Y., and Lehning, M.: Elevation dependency of mountain snow depth, The Cryosphere, 8, 2381-2394, https://doi.org/10.5194/tc-8-2381-2014, 2014.

Hedstrom, N. R. and Pimeroy, J. W.: Measurement and modelling of snow interception in the boreal forest, Hydrol. Process., 12, 1611-1625, https://doi.org/10.1002/(SICI)10991085(199808/09)12:10/113.0.CO;2-4, 1998.

Hopkinson, C., Sitar, M., Chasmer, L., and Treitz, P.: Mapping snowpack depth beneath forest canopies using airborne lidar, Photogramm. Eng. Rem. Sens., 70, 323-330, https://doi.org/10.14358/PERS.70.3.323, 2004.

IGOS - Integrated Global Observing Strategy: Cryosphere Theme Report - For the monitoring of our environment from space and from earth, WMO/TD-No. 1405, World Meteorological Organization, Geneva, 100 pp., 2007.

IPCC: Climate change 2013: The physical science basis. Contribution of working group I to the fifth assessment report of the intergovernmental panel on climate change, edited by: Stocker, T. F., Qin, D., Plattner, G.-K., Tignor, M. M. B., Allen, S. K., Boschung, J. B., Nauels, A., Xia, Y., Bex, V., and Midgley, P. M., Cambridge University Press, Cambridge, UK, and New York, USA, 1535 pp., 2013.

Ji, Z. and Kang, S.: Projection of snow cover changes over China under RCP scenarios, Clim. Dynam., 41, 589-600, https://doi.org/10.1007/s00382-012-1473-2, 2013.

Khaliq, M. N., Ouarda, T. B. M. J., Gachon, P., Sushama, L., and StHilaire, A.: Indentification of hydrological trends in the presence of serial and cross correlations: A review of selected methods and their application to annual flow regimes of Canadian rivers, J. Hydrol., 368, 117-130, 2009.

King, J. C., Pomeroy, J. W., Gray, D. M., Fierz, C., Fohn, P., Harding, R. J., Jordan, R. E., Martin, E., and Pluss, C.: Snowatmosphere energy and mass balance, in: Snow and Climate: Physical Processes, Surface Energy Exchange and Modeling, edited by: Armstrong, R. L. and Brun, E., Cambridge University Press, Cambridge, UK, 70-124, 2008.

Kitaev, L., Kislov, A., Krenke, A., Razuvaev, V., Martuganov, R., and Konstantinov, I.: The snow cover characteristics of northern Eurasia and their relationship to climatic parameters, Boreal Environ. Res., 7, 437-445, 2002.
Kitaev, L., Førland, E., Razuvaev, V., Tveito, O. E., and Krueger, O.: Distribution of snow cover over Northern Eurasia, Nord. Hydrol., 36, 311-319, 2005.

Kudryavtsev, V. A.: Principles of frozen ground forecasting during engineering and geocryological investigations (in Chinese), edited by: Cheng, G., translated from Russian by: Guo, D., Ma, S., and Ding, D., Lanzhou University Press, Lanzhou, China, 1992.

Kuusisto, E.: Snow accumulation and snowmelt in Finland, Publications of the Water Research Institute, v. 55, Valtion painatuskeskus, Helsinki, 149 pp., 1984.

Lazar, B. and Williams, M.: Climate change in western ski areas: potential changes in the timing of wet avalanches and snow quality for the Aspen ski area in the years 2030 and 2100, Cold Reg. Sci. Technol., 51, 219-228, https://doi.org/10.1016/j.coldregions.2007.03.015, 2008.

Lehning, M., Grünewald, T., and Schirmer, M.: Mountain snow distribution governed by an altitudinal gradient and terrain roughness, Geophys. Res. Lett., 38, L19504, https://doi.org/10.1029/2011GL048927, 2011.

Li, P. and Mi, D.: Distribution of snow cover in China, J. Glaciol. Geocryol., 5, 9-18, 1983.

Ling, F. and Zhang, T.: Modeling the effect of variations in snowpack-disappearence date on surface-energy balance on the Alaskan north slope, Arct. Antarct. Alp. Res., 37, 483-489, https://doi.org/10.1657/15230430(2005)037[0483:MTEOVI]2.0.CO;2, 2005.

Liston, G. E. and Hiemstra, C. A.: The changing cryosphere: PanArctic snow trends (1979-2009), J. Climate, 24, 5691-5712, https://doi.org/10.1175/JCLI-D-11-00081.1, 2011.

Ma, L. and Qin, D.: Spatial-temporal characteristics of observed key parameters for snow cover in China during 1957-2009, J. Glaciol. Geocryol., 34, 1-11, 2012.

Nayak, A., Marks, D., Chandler, D. G., and Seyfried, M.: Long-term snow, climate, and streamflow trends at the Reynolds Creek experimental watershed, Owyhee Mountains, Idaho, United States, Water Resour. Res., 46, W06519, https://doi.org/10.1029/2008WR007525, 2010.

Neter, J., Wasserman, W., and Kutner, M. H.: Applied linear regression model, IRWIN, Boston, 842 pp., 1989.

Park, H., Walsh, J. E., Kim, Y., Nakai, T., and Ohata, T.: The role of declining Arctic sea ice in recent decreasing terrestrial Arctic snow depths, Polar Sci., 7, 174-187, https://doi.org/10.1016/j.polar.2012.10.002, 2013.

Park, H., Fedorov, A. N., Zheleznyak, M. N., Konstantinov, P. Y., and Walsh, J. E.: Effect of snow cover on pan-Arctic permafrost thermal regimes, Clim. Dynam., 44, 2873-2895, https://doi.org/10.1007/s00382-014-2356-5, 2015.

Peng, S., Piao, S., Ciais, P., Fang, J., and Wang, X.: Change in winter snow depth and its impacts on vegetation in China, Global Change Biol., 16, 3004-3013, https://doi.org/10.1111/j.13652486.2010.02210.x, 2010.

Pomeroy, J. W., Bewley, D. S., Essery, R. L. H., Hedstrom, N. R., Link, T., Granger, R. J., Sicart, J.-E., Ellis, C. R., and Janowicz, J. R.: Shrub tundra snowmelt, Hydrol. Process., 20, 923-941, https://doi.org/10.1002/hyp.6124, 2006.

Rees, A., English, M., Derksen, C., Toose, P., and Silis, A.: Observations of late winter Canadian tundra snow cover properties, Hy- 
drol. Process., 28, 3962-3977, https://doi.org/10.1002/hyp.9931, 2014.

Revuelto, J., López-Moreno, J. I., Azorin-Molina, C., and VicenteSerrano, S. M.: Topographic control of snowpack distribution in a small catchment in the central Spanish Pyrenees: intraand inter-annual persistence, The Cryosphere, 8, 1989-2006, https://doi.org/10.5194/tc-8-1989-2014, 2014.

Robinson, D. A., Dewey, K. F., and Heim, R. R.: Global snow cover monitoring: An update, B. Am. Meteorol. Soc., 74, 1689-1696, https://doi.org/10.1175/15200477(1993)074<1689:GSCMAU>2.0.CO;2, 1993.

Scientific Knowledge: http://www.zgqxb.com.cn/kjzg/kpzl/kpzs/ 200911/t20091113_1701.htm, last access: 13 November 2009.

Storch, H. V.: Misuses of Statistical Analysis in Climate Research, in: Analysis of Climate Variability, edited by: Storch, H. V. and Navarra, A., Springer, Berlin, Heidelberg, Germany, 11-26, 1999.

Stuefer, S., Kane, D. L., and Liston, G. E.: In situ snow water equivalent observations in the US Arctic, Hydrol. Res., 44, 21-34, https://doi.org/10.2166/nh.2012.177, 2013.

Sturm, M., McFadden, J. P., Liston, G. E., Chapin III, F. S., Racine, C. H., and Holmgren, J.: Snow-shrub interactions in Arctic tundra: A hypothesis with climatic implications, J. Climate, 14, 336-344, https://doi.org/10.1175/15200442(2001)014<0336:SSIIAT>2.0.CO;2, 2001.

Tao, J., Zhang, X., Tao, J., and Shen, Q.: The checking and removing of the autocorrelation in climatic time series, J. Appl. Meteorol. Sci., 19, 47-52, 2008.

Terzago, S., Hardenberg, J. Palazzi, E., and Provenzale, A.: Snowpack changes in the Hindu Kush-Karakoram-Himalaya from CMIP5 global climate models, J. Hydrometeorol., 15, 22932313, https://doi.org/10.1175/JHM-D-13-0196.1, 2014.

Veselov, V. M.: PC archives of the State Data Holding and technology of their organization, Proceedings of the RIHMI-WDC (Russian Research Institute for Hydrometeorological InformationWorld Data Center), 170, 16-30, 2002.

Weatherhead, E. C., Reinsel, G. C., Tiao, G. C., Meng, X., Choi, D., Cheang, W., Keller, T., DeLuisi, J., Wuebbles, D. J., Kerr, J. B., Miller, A. J., Oltmans, S. J., and Frederick, J. E.: Factors affecting the detection of trends: Statistical considerations and applications to environmental data, J. Geophys. Res., 103, 17149-17161, https://doi.org/10.1029/98JD00995, 1998.

Wei, Z. and Dong, W.: Assessment of Simulations of Snow Depth in the Qinghai-Tibetan Plateau Using CMIP5 Multi-Models, Arct. Antarc. Alp. Res., 47, 611-625, https://doi.org/10.1657/AAAR0014-050, 2015.

WMO: Guide to meteorological instruments and methods of observation, WMO-No. 8, Geneva, Switzerland, 1996.
Xu, W., Ma, L., Ma, M., Zhang, H., and Yuan, W.: Spatialtemporal variability of snow cover and depth in the Qinghai-Tibetan Plateau, J. Climate, 30, 1521-1533, https://doi.org/10.1175/JCLI-D-15-0732.1, 2017.

Ye, H. C., Cho, H. R., and Gustafson, P. E.: The changes in Russian winter snow accumulation during 1936-83 and its spatial patterns, J. Climate, 11, 856-863, https://doi.org/10.1175/15200442(1998)011<0856:TCIRWS>2.0.CO;2, 1998.

Ye, K., Wu, R., and Liu Y.: Interdecadal change of Eurasian snow, surface temperature, and atmospheric circulation in the late 1980s, J. Geophys. Res.-Atmos., 120, 2738-2753, https://doi.org/10.1002/2015JD023148, 2015.

You, Q., Kang, S., Ren, G., Fraedrich, K., Pepin, N., Yan, Y., and Ma, L.: Observed changes in snow depth and number of snow days in the eastern and central Tibetan Plateau, Clim. Res., 46, 171-183, https://doi.org/10.3354/cr00985, 2011.

Zhang, T.: Influence of the seasonal snow cover on the ground thermal regime: An overview, Rev. Geophys., 43, RG4002, https://doi.org/10.1029/2004RG000157, 2005.

Zhang, T.: Progress in global permafrost and climate change studies, Quaternary Sci., 32, 27-38, https://doi.org/10.3969/j.issn.1001-7410.2012.01.03, 2012.

Zhang, T. and Zhong, X.: Classification and regionalization of the seasonal snow cover across the Eurasian continent, J. Glaciol. Geocryol., 36, 481-490, 2014.

Zhang, T., Osterkamp, T. E., and Stamnes, K.: Influence of the depth hoar layer of the seasonal snow cover on the ground thermal regime, Water Resour. Res., 32, 2075-2086, https://doi.org/10.1029/96WR00996, 1996.

Zhang, T., Barry, R. G., Gilichinsky, D., Bykhovets, S. S., Sorokovikov, V. A., and Ye, J.: An amplified signal of climatic change in soil temperatures during the last century at Irkutsk, Russia, Climatic Change, 49, 41-76, https://doi.org/10.1023/A:1010790203146, 2001.

Zhao, H., Higuchi, K., Waller, J., Auld, H., and Mote, T.: The impacts of the PNA and NAO on annual maximum snowpack over southern Canada during 1979-2009, Int. J. Climatol., 33, 388395, https://doi.org/10.1002/joc.3431, 2013.

Zheng, L., Zhang, T., Che, T., Zhong, X., and Wang, K.: Evaluation of snow depth products derived from passive microwave satellite remote sensing data using ground-based snow measurements, Remote Sens. Technol. Appl., 30, 413-423, 2015.

Zhong, X., Zhang, T., and Wang, K.: Snow density climatology across the former USSR, The Cryosphere, 8, 785-799, https://doi.org/10.5194/tc-8-785-2014, 2014. 